\title{
ДЕМОГРАФИЧЕСКИЙ ПЕРЕХОД И ГИПОТЕЗА ГИПЕРБОЛИЧЕСКОГО РОСТА НАСЕЛЕНИЯ
}

\author{
АНАТОЛИЙ ВИШНЕВСКИЙ
}

\begin{abstract}
В статье анализируется трактовка демографического перехода сторонниками гипотезы гиперболического роста населения. Автор приходит к выводу, что за последние два-три десятилетия в работах ряда российских и некоторых зарубежных авторов, разделяюших эту гипотезу, получила развитие система представлений о закономерностях демографического развития и о демографическом переходе как современном этапе этого развития, альтернативная общепринятой. Задача статьи заключается не столько в том, чтобы выразить несогласие с предложенной альтернативой, сколько в том, чтобы показать отличие содержашихся в ней подходов и их следствий от уже сложившихся представлений. В то же время автор выражает критическое отношение к ряду постулатов, на которых основывается гипотеза гиперболического закона, прежде всего к лежащему в ее основе постулату самодостаточности демографического роста и его независимости от внешних условий.
\end{abstract}

Ключевые слова: теоретическая демография, демографический переход, демографический взрыв, экспоненциальный рост, логистический рост, гиперболический рост, демографический императив, технологический императив, жизнесберегающие технологии, неолитическая демографическая револючия, неолитический кризис смертности.

\section{ВВЕДЕНИЕ}

Много лет назад, рассматривая вопрос об исторической динамике численности человечества, я натолкнулся на трудности истолкования роста населения Земли после «неолитической демографической революции». «По логике рассуждения, окончание демографической революции и утверждение традиционного типа воспроизводства населения должно положить конец и периоду высоких темпов роста его численности, так что этот рост снова должен смениться относительной стабильностью. Между тем все оценки говорят о том, что на протяжении последних 10 тыс. лет темпы роста числа людей на Земле имели общую тенденцию к увеличению» [Вишневский 1982: 68]. Я попытался показать, что отмеченное противоречие - кажущееся и возникает из-за того, что среднемировые темпы роста складываются из темпов роста отдельных, относительно изолированных населений, которые могут находиться на разных стадиях демографического развития. В то время, как одни еще не вошли в стадию роста, в других этот рост идет высокими темпами, а в третьих он уже прекратился. Увеличение числа населений, находящихся в стадии роста и обеспечивает общее ускорение роста [Там же].

\footnotetext{
АНАТОЛИЙ ГРИГОРЬЕВИЧ ВИШНЕВСКИЙ (avishnevsky@hse.ru), НАЦИОНАЛЬНЫЙ ИССЛЕДОВАТЕЛЬСКИЙ УНИВЕРСИТЕТ «ВЫСШАЯ ШКОЛА ЭКОНОМИКИ», РОССИЯ.

СТАТЬЯ ПОСТУПИЛА В РЕДАКЦИЮ В ДЕКАБРЕ 2017 Г.
} 
Это словесное рассуждение, подкрепленное примитивными, a, возможно, и ошибочными графиками, не казалось мне неверным (и не кажется сейчас), но я чувствовал, что оно нуждается в более строгом и формализованном рассмотрении, которое может дать только математическая модель. Я искал кого-нибудь, кто мог бы мне помочь в построении такой модели и в этой связи несколько раз разговаривал с С.П. Капицей, научные интересы которого в то время обратились к демографии. К сожалению, предложенная им модель меня не удовлетворила. Я честно сказал ему об этом, и мы больше никогда не возвращались к ее обсуждению, при том, что сохраняли самые добрые и довольно регулярные отношения до последних дней его жизни. В своих книгах он указывает, что я участвовал в его исследованиях.

Модель С.П. Капицы, подробно описанная им вначале в статьях (см., напр. [Капица 1992; 1996]), а затем и в двух близких по содержанию книгах [Капица 1999а; Капица 1999 $]$ ], не удовлетворила меня потому, что, по моим представлениям, он умножал сущность без надобности, усложнял и мистифицировал всю картину роста населения Земли на протяжении человеческой истории, в то время как она без больших проблем может быть истолкована в рамках привычных экологических, социологических, экономических и, конечно, демографических представлений.

Впрочем, нельзя исключить того, что я просто не понял и не оценил каких-то важных инновационных подходов модели Капицы, потому что у нее появилось большое число сторонников и продолжателей. Предложенная им модель гиперболического роста используется и развивается во многих публикациях, статья А. Подлазова «Глобальная демографическая теория» [Подлазов 2018] ${ }^{1}$ - одна из них.

Задача моей статьи заключается не столько в том, чтобы выразить несогласие с моделью гиперболического роста, сколько в том, чтобы показать отличие содержащихся в ней подходов и их следствий от уже сложившихся представлений.

\section{ФЕНОМЕНОЛОГИЧЕСКАЯ МОДЕЛЬ}

Статья А. Подлазова, как он сам пишет, посвящена построению математической теории глобального демографического процесса, охватывающей как стадию демографического роста, так и стадию демографического перехода. Я коснусь обоих этих вопросов, но больше внимания уделю второму - стадии демографического перехода и ее отражению в демографической теории.

Как и С. Капица, А. Подлазов называет свою модель демографического перехода «феноменологической», хотя, возможно, они вкладывали в это понятие разный смысл.

В свое время, Вернер Гейзенберг, размышлявший о роли феноменологических теорий в физике, отмечал, что такие теории полезны и развиваются в тех случаях, когда

\footnotetext{
${ }^{1}$ См. стр. 39-63 этого номера «Демографического обозрения». В дальнейшем при цитировании этой статьи указываются только номера страниц.
} 
«наблюдаемые явления еще не могут быть сведены к общим законам природы» [Гейзенберг 1967: 731]. Причиной такой невозможности, утверждал Гейзенберг, может быть либо чрезвычайная сложность наблюдаемых явлений, которая не допускает такого сведения изза математических трудностей, либо незнание упомянутых законов. Во втором случае можно надеяться, что феноменологическая теория приблизит нас к пониманию этих законов, но так бывает не всегда. В качестве примера Гейзенберг приводит описание движения планет в астрономии Птолемея, по поводу которого он говорит, что «успешная, но все же только формальная феноменологическая теория на полторы тысячи лет преградила путь к познанию истинного движения планет» [Там же: 733].

С. Капица связывал особенности феноменологического подхода с тем, что при таком подходе «ищутся законы, описывающие систему в целом», благодаря чему он оказывается плодотворным тогда, «когда детальная, микроскопическая картина явлений очень сложна, a механистический редукционизм оказывается бессильным, чтобы в реальном, макроскопическом, масштабе охватить всю совокупность явлений» [Капица 1999: 17]. Таким образом, обращение к феноменологической модели, в данном случае, объясняется, скорее, первой из названных Гейзенбергом причин - «чрезвычайной сложностью наблюдаемых явлений»; в качестве одного из примеров таких моделей Гейзенберг приводил «полуэмпирические закономерности, применяемые для описания погоды в метеорологии» [Гейзенберг 1967: 731]. Но мне все же кажется, что рост мирового населения - сам по себе макроскопический процесс, и его понимание не требует перехода на микроскопический уровень. У метеорологов могут быть трудности с предсказанием погоды на ближайшие несколько дней, но смену времен года предсказать нетрудно.

Обращение к феноменологической модели А. Подлазова, судя по тому, что сам он пишет, продиктовано второй из названных Гейзенбергом причин: еще не сформулированы «первые принципы, из которых можно было бы строго вывести формулы, описывающие демографический переход», и приходится «угадывать» ключевые факторы, определяющие ход этого процесса [51]. Не слишком ли категорично такое утверждение? Даже у Птолемея были предшественники, которые видели мироздание не так, как он, и, несмотря на его полуторатысячелетнюю славу, были правы (Аристарх Самосский с его гелиоцентрической картиной мира).

Теория демографического перехода развивается - силами немалого числа исследователей - более ста лет, ее «первые принципы», как мне кажется, давно сформулированы, и основные движущие силы этого процесса, так же, как и препятствия, на которые он наталкивается, абсолютно ясны. Это не значит, что теория демографического перехода в том виде, в каком она сложилась к настоящему времени, не допускает критического отношения и даже полного низвержения в случае, если будет доказана ее несостоятельность. Критика и ниспровержение научных парадигм - нормальный этап развития научного знания.

Менее обычна ситуация, когда некая система представлений выстраивается рядом с существующей без ее критики, а иногда даже и без ее упоминания, как будто новая научная конструкция воздвигается на пустом месте. Именно с такой ситуацией столкнулась в последние годы демографическая наука, по крайней мере, российская. В частности, 
возникло нечто вроде альтернативной теории демографического перехода, а вместе с тем и демографической динамики в целом.

Отражение этой ситуации мы и видим в статье А. Подлазова. Видимо, его не удовлетворяет существующая объяснительная схема демографического перехода, и он пытается выстроить ее заново. Одно из первых оснований неудовлетворенности заключается в том, что эта схема не облечена в строгую математическую форму. Во всяком случае, в статье утверждается, что «ключевой нерешенной проблемой теоретической демографии остается построение математической модели демографического перехода» [61].

Построить математическую модель любого процесса, не опираясь на определенные содержательные представления, касающиеся «физического смысла» моделируемого процесса, нельзя. Разумеется, такие представления есть и у А. Подлазова, но они существенно отличаются от тех, какие приняты в современной демографической науке.

Интересно, что отличия не затрагивают конечных выводов. Модель А. Подлазова «предполагает постпереходную стабилизацию населения мира», и в этом смысле не отличается от «классической» теории демографического перехода - её предположения о постпереходной стабилизации давно закладываются во все глобальные прогнозы. Нет ничего нового и в понимании демографического перехода как движения от экстенсивного к интенсивному типу воспроизводства населения. Это хорошо видно из приведенных чуть ниже высказываний демографов, гораздо более определенных, чем у А. Подлазова, ведь у него речь идет лишь о том, что такое движение «весьма вероятно». Наконец, если отвлечься от экстравагантности формулировки («элиминация «лишних» людей»), то давно сложилось понимание того, что демографический переход включает в себя снижение рождаемости, запаздывание которого может обернуться катастрофическими подъемами смертности. Если что и вызывает сомнение, то это падение рождаемости во многих странах ниже уровня воспроизводства, которое заставляет некоторых авторов усомниться в правильности теории демографического перехода. Однако и такое падение вполне объяснимо, если рассматривать современное население мира не как сумму населений отдельных стран, а как единую систему [Vishnevsky 2004: 274; Вишневский 2008: 83-84], к чему как раз и призывают сторонники гипотезы гиперболического роста.

Особенность модели А. Подлазова заключается не в выводах, как мне кажется, достаточно банальных и сделанных ранее и независимо от этой модели, а в самой логике ее построения, сильно отличающейся от логики построения «классической» модели демографического перехода, да и всего демографического процесса. Логика А. Подлазова (как и других сторонников гипотезы гиперболического роста), о которой речь пойдет ниже, ведет к неожиданным и весьма спорным взглядам на природу того и другого.

«Классическая» теория, при всех различиях и нюансах в ее трактовке разными авторами, всегда исходит из того, что демографический переход представляет собой часть фундаментальных общественных трансформаций Нового и Новейшего времени, резко расширивших возможности контроля человека над своим экономическим, социальным и демографическим бытием. Что же касается понимания А. Подлазова, то, как утверждают 
авторы, полагающие, что его работа, «безусловно, является шагом вперед в области теоретической демографии», он ищет причину демографического перехода «в самом естестве человека, его биологических параметрах и продолжительности жизни» и приходит к выводу, что переход, «связан не с какими-то ни было ресурсными ограничениями, а исключительно с внутренними особенностями человеческого организма» [Коротаев и соавт. 2007ª: 171, 173].

Подобная необычная трактовка А. Подлазовым и некоторыми другими российскими исследователями демографического перехода исходит из их общего видения демографической истории, которое также сложилось, по-видимому, под влиянием работ С. Капицы и развивавшейся им теории гиперболического роста населения, хотя упоминаются и другие ее источники.

\section{«КЛАССИЧЕСКОЕ》 ОБЪЯСНЕНИЕ ДЕМОГРАФИЧЕСКОГО ПЕРЕХОДА}

Демографическая революция, или демографический переход ${ }^{2}$, одно из главных событий человеческой истории последних трех столетий, хотя его научное осмысление началось лишь в начале XX в. Несмотря на более чем столетнюю историю изучения демографической революции, восходящую к публикации Адольфа Ландри 1909 г. [Landry 1982], в понимании ее смысла, детерминант и последствий остается множество спорных и нерешенных вопросов [Вишневский 2017], что вполне естественно, когда речь идет о столь многоплановом, сложном и масштабном историческом феномене. Тем не менее есть и такие вопросы, по которым в демографической науке существует достаточно прочный консенсус.

Если не говорить о ранних этапах развития теории демографического перехода, то ее основное ядро сложилось в работах американских демографов в 1940-е - 1950-е годы. Именно тогда был достаточно четко осознан смысл демографической революции, с одной стороны, как уникального, а с другой, - как прогрессивного этапа всемирной демографической истории. Как писал тогда один из классиков американской демографической школы Кингсли Дэвис, на протяжении 99 процентов человеческой истории «рост населения Земли был похож на медленное и неуверенное движение пламени по длинному тонкому фитилю, пока, наконец, огонь не достигает порохового заряда и не взрывается. В течение миллиона или более лет наш вид увеличивался с бесконечной медлительностью, временно расцветая в некоторых областях мира, но в других районах почти не зная роста». И даже после появления сельского хозяйства «население мира, в отличие от населения отдельных районов, росло настолько медленно, что, по современным стандартам, казалось стационарным» [Davis 1945³: 1].

Изменения произошли только тогда, когда началась промышленная революция, трактуемая Дэвисом широко - как совокупность технологических, экономических, социальных и политических перемен. Эти перемены обусловили быстрое снижение

\footnotetext{
2 Эти термины я рассматриваю как синонимы, хотя и считаю термин «демографическая революция» более точным. Но в этой статье я чаще пользуюсь термином «демографический переход», потому что его используют все авторы, которых я цитирую.

${ }^{3}$ Цитируемая статья - первая, где термин «демографический переход» встречается в названии статьи.
} 
смертности, за которым последовало снижение рождаемости, а в конечном счете установление «нового демографического баланса». Но так как снижение рождаемости отставало от снижения смертности, то между ними возник разрыв, приведший к «огромному росту европейского населения». Этот этап оказался временным, снижение рождаемости «догоняет», а иногда и «перегоняет» снижение смертности, вследствие чего численность населения в странах Западной Европы снова становится стабильной или даже убывающей. Но так как снижение смертности распространилось теперь на страны неевропейской культуры, то туда переместился и демографический взрыв, обусловленный лагом между снижением смертности и рождаемости. Впрочем, и здесь этот лаг - временное явление, и «вполне вероятно, что в следующем столетии будет достигнут пик роста населения всего мира, а новый демографический баланс распространится повсеместно» [Там же: 11].

Второй ключевой тезис статьи Дэвиса заключался в том, что переход к новому демографическому балансу «представляет собой поразительный выигрыш в эффективности человека». «Новый тип демографического баланса высвободил огромное количество энергии из вечной цепи воспроизводства - энергии, которая могла быть потрачена на другие аспекты жизни» [Там же: 5]. Эту мысль впоследствии хорошо выразил М. ЛивиБаччи: «Демографический переход может быть охарактеризован как изменение системы, как переход от «диссипативной» системы, связанной с потерей демографической энергии (высокие рождаемость и смертность), к системе, «экономизирующей» эту энергию (низкие рождаемость и смертность» [Livi-Bacci 1995: 451]. Важность этого тезиса заключается в том, что он указывает на эволюционные преимущества нового типа демографического баланса, которые и объясняют его утверждение в процессе исторического развития и вытеснение предыдущего, менее эффективного его типа.

Концепция демографической революции (демографического перехода) в том виде, в каком она была только что кратко описана, получила широкое распространение и, как мне представляется, приобрела значение научной парадигмы в том смысле, какой вкладывает в это понятие Т. Кун. Она «достаточно беспрецедентна, чтобы привлечь на длительное время группу сторонников из конкурирующих направлений научных исследований», и в то же время «достаточно открыта, чтобы новые поколения ученых могли в ее рамках найти для себя нерешенные проблемы любого вида» [Кун, 1977: 28]. Многие положения общей концепции получают дальнейшее развитие или, напротив, могут оспариваться. Но общее представление о демографическом переходе как о смене демографического баланса, фундаментальном сдвиге от равновесия высокой смертности и высокой рождаемости, существовавшего на протяжении всей человеческой истории, к новому равновесию низкой смертности и низкой рождаемости, неизменно лежит в основе большинства научных интерпретаций наблюдаемых перемен, прогнозов будущих демографических тенденций, а нередко способствует и пониманию исторически отдаленных от нас событий.

Что нового, по сравнению с этой схемой, несет с собой гипотеза гиперболического роста населения и насколько она обоснована? 


\section{ДВЕ КАРТИНЫ РОСТА МИРОВОГО НАСЕЛЕНИЯ}

Построение феноменологической теории не претендует на полное раскрытие внутренних механизмов изучаемого феномена, но все же предполагает наличие достаточной информации о самом феномене. Птолемей неверно объяснял законы движения планет, но само это движение он имел возможность наблюдать и знал о нем достаточно много. К сожалению, наблюдение изменений численности населения на протяжении человеческой истории гораздо менее доступно, чем наблюдение звездного неба.

Как отмечает А. Подлазов, сколько-нибудь подробные демографические данные по всему миру до середины XX в. отсутствуют, поэтому для построения реальной зависимости темпов роста населения от его численности он использовал данные, взятые из работы М. Кремера. Если бы речь шла только о трех-четырех последних столетиях, то против этого ничего нельзя было бы возразить. Для этого периода имеются пусть и не самые точные, но более или менее обоснованные оценки, сделанные в разное время, с определенными оговорками их можно использовать. Гипотеза же гиперболического роста претендует на то, что она опирается на реальные данные за все время существования человечества. Откуда берутся эти данные? Если, как признает А. Подлазов, они вообще отсутствуют, то откуда они взялись у Кремера, либо у Диви или у МакЭведи и Джонса, у которых Кремер, в свою очередь, их заимствовал [Kremer 1993: 683]? В действительности имеются только некоторые приводящиеся в литературе приблизительные оценки, которые очень сильно расходятся. Например, оценки численности населения Земли за 5 тыс. лет до н.э. колеблются в диапазоне о 5 до 24 млн человек, за тысячу лет до н.э. - от 50 до 154 млн. [HYDE 2011]. На подобный разброс оценок обращают внимание, в частности, Коротаев и соавторы [Коротаев и соавт. 2010: 14-16], но он их не смущает. В любом случае, они полагают, что вероятность того, что общая тенденция динамики численности населения Земли «с 40000 г. до н.э. по 1970 г. н.э. была не гиперболической, ... практически не отличается от нуля» [Там же: 19].

Впрочем, высказываются и другие мнения. «Анализ результатов, полученных классиками закона гиперболического роста численности мирового населения, показывает, что они основаны почти исключительно на оценках за 1650-1970 гг. В другие периоды динамика численности населения подчинялась другим законам, причем этапы роста, отождествимые с движением по аттракторам, сменялись этапами стагнации, которые можно рассматривать как точки бифуркации» [Кононов 2015: 92]. Но к таким замечаниям сторонники закона гиперболического роста обычно не прислушиваются.

Объединение и усреднение всех имеющихся приблизительных оценок [Goldewijk et al. 2010; HYDE 2011] позволяет построить усредненную кривую численности мирового населения за всю историю его существования (рис. 1), но изначально ясно, что это приблизительная, идеализированная, сглаженная кривая, такая идеализация заложена в самой процедуре оценок. Имея крайне ограниченную и ненадежную информацию о реальных величинах, авторы оценок должны были стремиться к их правдоподобию и сообразовывать их со им своими самыми общими априорными представлениями об исторической динамике мирового населения. 
Таким образом, А. Подлазов и другие сторонники теории гиперболического роста, строя свои модели, имеют дело не с реальныли эмпирическими данными, а с квазиэмпирической моделью, построенной другими исследователями, и оценивают успешность своих модельных построений, исходя из того, насколько построенные ими графики соответствуют тому, что они называют реальными данными, но что, на самом деле, таковыми не является.

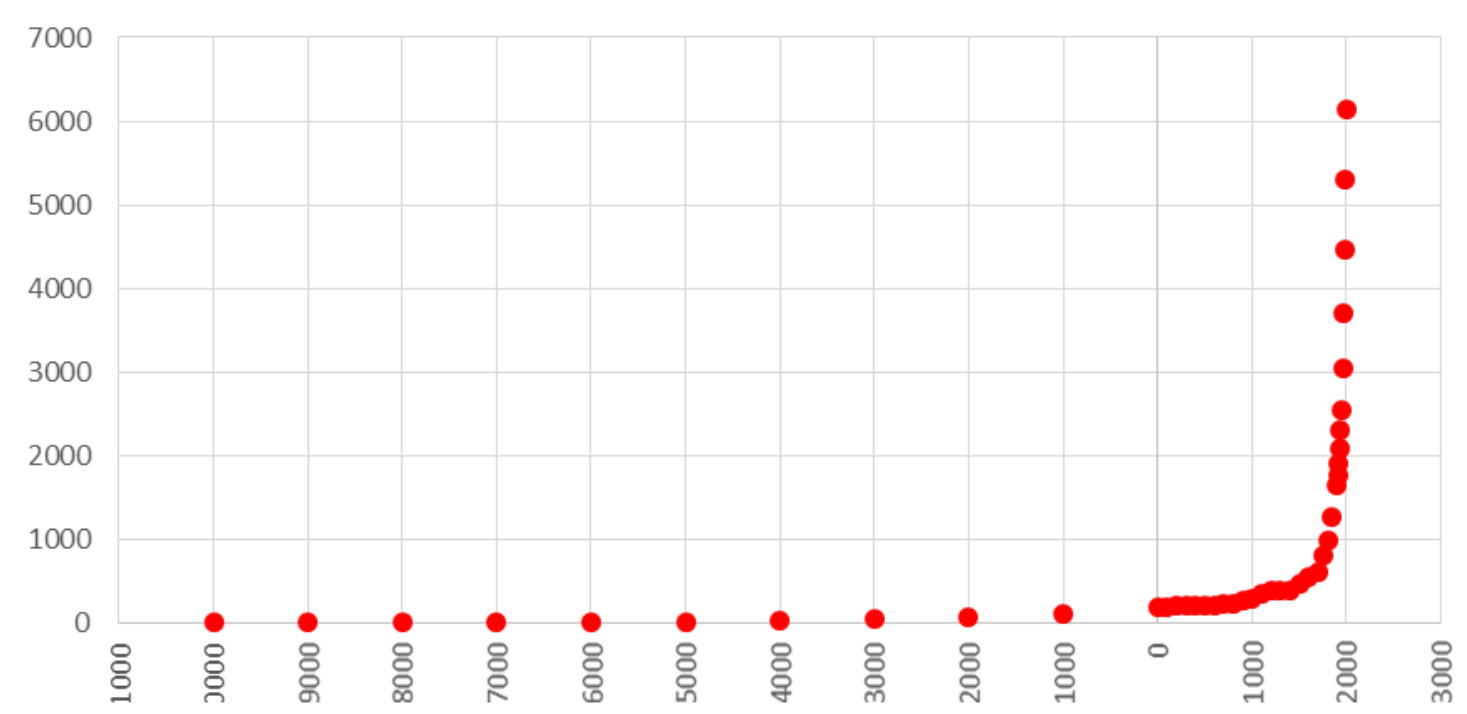

Рисунок 1. Квазиэмпирическая модель роста населения Земли за последние 12000 лет

Источник: HYDE (History Database of the Global Environment 3.1) (2011). Netherlands Environmental Assessment Agency (PBL). URL:

http://themasites.pbl.nl/tridion/en/themasites/hyde/basicdrivingfactors/population/index-2.html (dama обращчения: 18.02.2018).

При этом они либо игнорируют, либо не знают того, что сами авторы оценок, которыми они оперируют, прекрасно понимали их условность, равно как и предельно обобщенный характер кривых, подобных той, что приведена на рис. 1, и рассматривали ее лишь как самый первый шаг к пониманию того, как же, на самом деле, росло население нашей планеты.

Одним из таких авторов был Эдвард Диви-младший. Его оценки, численности населения за период с 10000 года до н.э. приведенные в хорошо известной демографам статье The Human Population [Deevey 1960], принял Крамер, а значит и те, кто заимствует их у Крамера, хотя сам Диви относился к ним достаточно скептически, полагая, что основания оценок до 1650 г. ненадежны, «можно подозревать, что авторы копируют догадки друг друга» [Deevey 1960: 197]. Важнее, однако, другое.

Диви тоже рисовал график, подобный тому, какой представлен на рис.1, но лишь для того, чтобы сказать, что, при выбранном масштабе, различия в оценках на большем протяжении графика не имеют большого значения и «теряются в толщине линии чертежника» [Там же: 197], - это заставляет вспомнить о «длинном тонком фитиле» Кингсли Дэвиса. Вместо этого графика он представил принципиально иной схематический график (рис. 2), который опирался не на немногочисленные и ненадежные количественные 
оценки, а на содержательные представления, накопленные к тому времени экологами, историками и демографами.

На графике Диви кривая численности населения Земли вовсе не подчинена закону непрерывного роста, а движется вверх, проходя крупные циклы, обусловленные «тремя главными революциями, которыми отмечено развитие культуры», причем кривые указывают также на «приближение к равновесию в двух межреволюционных периодах прошлого» [Там же: 195].

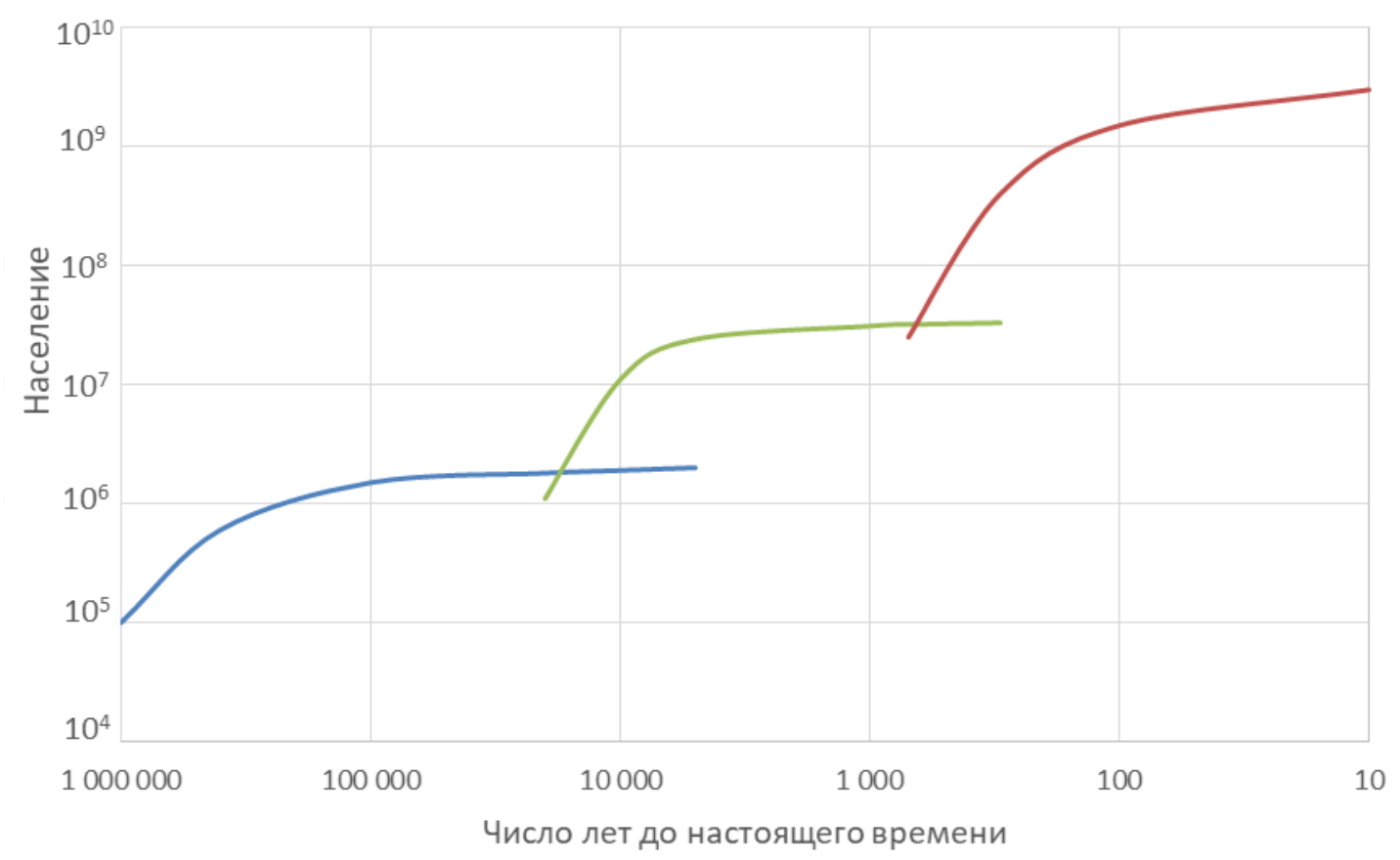

\section{Рисунок 2. Три скачка роста населения планеты (двойная логарифмическая шкала)}

Источник: [Deevey 1960: 198].

Первая революция заключалась в овладении производством орудий и привела к первому скачку численности человечества. По оценке Диви, к 5000 г. до н.э. население Земли составило, примерно, 5 млн человек при средней плотности 0,4 человека на квадратный километр (как упоминалось, есть и более высокие оценки численности населения в это время, сделанные другими авторами). Вторая революция - возникновение сельского хозяйства - создала условия для нового скачка, население, согласно Диви, выросло на два порядка, а плотность увеличилась, в среднем, до одного человека на квадратный километр. Наконец, третья - научно-промышленная - революция дала толчок новому огромному росту населения, который идет последние 300 лет и еще не окончился.

Со времени появления статьи Диви прошло более полувека, какие-то его количественные оценки могут быть оспорены, но нарисованная им качественная картина полностью соответствует современным взглядам историков-демографов. Они утверждают, что население мира «не знало непрерывного экспоненциального роста, о котором в некоторых работах говорится как об общепризнанной истине» [Birabin 2006: 15]. При этом различаются рядовые колебания численности населения, которые имели место во все периоды истории и предыстории, и скачки, имевшие необычную величину и приводившие 
к резкому и значительному росту населения с последующей его стабилизацией. Такие скачки, как это было и у Диви, связываются с тремя революциями. Первой была верхнепалеолитическая революция, приведшая к совершенствованию орудий, технологии охоты и рыбной ловли, оборудования стоянок, изготовления одежды, овладению огнем и т.п. Второй стала неолитическая революция - переход к сельскому хозяйству и оседлости со всеми вытекающими отсюда экономическими и социальными последствиями. Третья революция происходит в наше время и сопряжена с индустриализацией, урбанизацией, научно-технической революцией, глобализацией и т.п. [Там же: 15-16].

Когда революции заканчивались рост населения надолго замедлялся, хотя едва ли можно говорить о его полном прекращении, как это иногда делают. Например, применительно к самому длительному периоду человеческой истории - палеолиту высказываются крайние суждения, отрицающие всякий рост населения в эту эпоху. «Наиболее бесспорный демографический постулат, касающийся доисторических населений, заключается в том, что если рассматривать длительные периоды времени и усреднить внезапные подъемы и спады населения с последующим возвратным движением, то рост числа людей был близок к нулю» [Caldwell, Caldwell 2003: 153]. Это утверждение, скорее всего, не вполне точно. Рост населения Земли шел и в палеолите, хотя, конечно, он был очень медленным и при попытке отразить его на едином для всей истории человечества графике он неизбежно потеряется «в толщине линии чертежника». Но если бы его совсем не было, то каким образом люди именно в эту эпоху смогли бы расселиться по всей планете?

Неолитическая революция, суть которой заключалась в появлении сельского хозяйства и переходе от присваивающей к производящей экономике, привела к тому, что долгое, медленное и постепенное увеличение числа людей на Земле сменилось его стремительным ростом - это факт, который сегодня не оспаривается никем. С распространением сельского хозяйства, «население выросло на несколько порядков, а потолок, предписанный экосистемой охотникам-собирателям, резко поднялся» [Livi-Bacci 2012: 35]. «Ни один аспект человеческого общества не был так радикально, немедленно и необратимо изменен «неолитической революцией», как количественный» [McEvedy and Jones 1979: 343].

Как полагают МакЭведи и Джонс, темпы роста достигли своего пика около 1000 г. до н.э., что совпало с началом железного века в Европе и на Ближнем Востоке. Время удвоения населения сократилось с 1000 лет до 500; примерно в 500 г. до н.э. число людей на Земле превысило 100 млн. «Никогда еще так много людей не умножалось так быстро. Однако, хотя абсолютные числа продолжали расти - до 150 млн ко II в. до н. э. и около 200 млн ко II в. н.э., темпы роста начали снижаться. Выигрыш за период с 500 г. до н.э. до I в. н.э. составил 70\%, а не 100\%; в течение следующих 200 лет добавилось всего 12\%, а затем рост полностью прекратился. Цикл, начавшийся 6000 лет назад, <...> завершился» [Там же: $343]$.

И здесь, по-видимому, есть некоторое преувеличение - едва ли можно утверждать, что рост прекратился полностью. Прекратился лишь «неолитический демографический 
взрыв», население продолжало расти, по-разному в разных частях мира, но в целом по миру - уже не взрывными темпами. По оценке тех же МакЭведи и Джонса, за первое тысячелетие Новой эры население мира выросло на 56\%, в том числе население Европы - на 16 \%, Азии - на $61 \%$, Африки и Америки - вдвое [Там же: $18,122,206,270]$. Однако во второй половине второго тысячелетия темпы роста населения снова стали нарастать, и в XVIII в. появились признаки нового демографического взрыва, который стал очевиден сначала в Европе в XIX в., а в XX в. приобрел глобальный характер.

Вся эта довольно подробно изученная картина совсем не вяжется с категорическим утверждением А. Подлазова. «Принципиальной особенностью глобального демографического процесса является то, что на протяжении большей части истории он шел с ускорением..., которое лишь недавно сменилось замедлением... Ускоряющийся характер роста выражается в том, что со временем увеличивается не только численность населения, но также его годовой прирост (производная) и даже темп прироста (логарифмическая производная)» [40]. Это утверждение, касающееся «большей части истории» он иллюстрирует графиком темпов роста населения за 1750-2050 гг., т.е. за период после начала демографического взрыва. По-видимому, совершенно необычная, исключительная, «переходная», заведомо временная ситуация глобального демографического взрыва, механизм возникновения и прекращения которого абсолютно ясен, трактуется А. Подлазовым как заурядное проявление универсального закона гиперболического роста. Преодоление же этой временной необычности, вполне ожидаемое, он истолковывает как небывалый отход от этого закона, соблюдавшегося «от нижнего палеолита до возникновения постиндустриального общества» [42]. Само представление о демографическом взрыве он связывает не с небывалым ускорением роста населения, что кажется вполне естественным, а с переходом к его замедлению («переход от ускорения к замедлению породил представление о демографическом взрыве» [40]). Соответственно, согласно А. Подлазову, постпереходная стабилизация - это не результат возвращения к прежней относительной стабильности, как принято считать в рамках «классических» представлений, а небывалое замедление роста населения, который до этого всегда росло в соответствии с «гиперболическим законом».

\section{ЗАЗОР МЕЖДУ РОЖДАЕМОСТЬЮ И СМЕРТНОСТЬЮ}

Попытки найти математический закон, дающий обобщенное представление о демографической динамике, предпринимаются давно. Поначалу простейшие предположения о росте населения, не испытывающего каких-то необычных потрясений и не знающего миграции («закрытое население»), естественным образом приводили к предположению о постоянном темпе роста, а значит, и об увеличении населения в геометрической прогрессии. В 1767 г. Леонард Эйлер опубликовал работу под названием «Общие исследования о размножении человеческого рода» [Euler 1767], в которой исходил именно из этого предположения. «Во всех своих работах, при самых разнообразных гипотезах о рождаемости и смертности - Эйлер неизменно приходит к заключению о том, что в замкнутом населении числа родившихся (а следовательно и численность населения) должны расти в геометрической прогрессии» [Паевский 1935: 107]. 
Логичное, но формальное предположение Эйлера, которое разделяли и другие авторы XVIII в., было приближено к жизни Т.-Р. Мальтусом. Следуя за Эйлером (Мальтус упоминает также У. Петти), он писал, что можно «признать несомненным то положение, что если возрастание населения не задерживается какими-либо препятствиями, то это население удваивается через каждые 25 лет и, следовательно, возрастает в каждый последующий двадцатипятилетний период в геометрической прогрессии» [Мальтус 1993: 12]. Но одновременно Мальтус утверждал, что «мы не знаем ни одной страны, в которой население возрастало бы беспрепятственно» [Там же: 11]. Соединение этих двух тезисов имело много важных последствий, в частности же, поставило под сомнение гипотезу экспоненциального роста - применительно не только к людям, но ко всему живому («природа щедрой рукой рассыпала зародыши жизни..., но она бережлива относительно места и пищи для них» [Там же]). Существование препятствий должно прогрессивно снижать темпы роста населения по мере усиления препятствий. Учет этого обстоятельства привел к появлению логистической модели П.Ф. Ферхюльста, получившей всеобщее признание в экологии и демографии. Она описывает обратную зависимость темпов роста популяций растений, животных и людей от плотности на обобщенную единицу ресурса (обычно на единицу пространства или объема), что можно интерпретировать как результат действия отрицательных обратных связей.

Гипотеза гиперболического роста человечества претендует на то, чтобы стать новым словом в развитии представлений о популяционной динамике. Она означает, что темпы роста человеческих популяций, населения, исключаются из общего правила, в отличие от популяций растений и животных, не зависят от плотности и не только не сокращаются по мере ее увеличения, но, напротив, неуклонно растут, как если бы рост населения порождал положительные обратные связи. С. Капица назвал такое обобщение принципом демографического императива, согласно которому «развитие демографической системы в большей степени подчинено собственным системным закономерностям, чем внешним факторам и обстоятельствам» [Капица 1999а: 34]. Именно этот краеугольный камень гипотезы гиперболического роста, на который опирается А. Подлазов, и вызывает наибольшие сомнения.

Несмотря на достаточно сложный для не математика язык статьи А. Подлазова, ему все-таки приходится в каком-то месте статьи объяснить, что в его понимании темпы роста населения - это просто коэффициент естественного прироста, т.е. разница между коэффициентами рождаемости и смертности. Такое понимание, конечно, не соответствует действительности, потому что на всех этапах истории неизменно присутствовал третий компонент роста населения - миграция. А. Подлазов, вслед за С. Капицей, исключает ее из рассмотрения на том основании, что при планетарных масштабах их анализа можно говорить только о миграционном обмене с другими планетами, а его не было. Но если рассматривать модель А. Подлазова как некую теоретическую абстракцию, полезную для упрощения анализа, то можно принять его правила игры. В конце концов, можно толковать прибытие людей в некую их совокупность или их убытие из нее как аналоги рождения и смерти. 
Итак, сосредоточимся, как это и делает А. Подлазов, на разнице между коэффициентами рождаемости и смертности ${ }^{4}$. Согласно его теории, эта разница все время увеличивается, и сам собой возникает вопрос: почему и как это может происходить. Ответов на этот вопрос может быть только три: либо снижается смертность (при неизменной или более медленно снижающейся рождаемости); либо повышается рождаемость (при неизменной или более медленно повышающейся смертности); либо одновременно снижается смертность и повышается рождаемость.

Ответ А. Подлазова однозначен: все дело в снижении смертности. Центральное место в его рассуждениях занимает «расширение технологической ниши человечества вследствие развития им жизнесберегающих технологий, мерой которого служит обусловленное ими сокращение коэффициента смертности» [60]. Развитие жизнесберегающих технологий объясняется «коллективным эффектом», способностью людей к кооперации, взаимопомощи. Рост населения, «в свою очередь приводит к дальнейшему усилению ее [взаимопомощи] роли и снижению смертности». Говоря несколько более обобщенно, рост населения приводит к возникновению тех самых положительных обратных связей, а значит, и к ускорению этого роста, вследствие чего «на протяжении почти всей истории вида Homo sapience его численность росла в режиме с обострением» [39].

Вклад повышения рождаемости в увеличение зазора между коэффициентами рождаемости и смертности А. Подлазов отвергает. В обоснование своей позиции он приводит несколько аргументов, которые кажутся ему убедительными, и в дальнейших своих рассуждениях считает уровень рождаемости «неизменным в фазе демографического роста и снижающимся во время демографического перехода» [44].

Не будем пока касаться этого обобщенного представления, а посмотрим лишь на то, в какой мере гипотеза А. Подлазова соответствует известным фактам об изменениях смертности и рождаемости на протяжении человеческой истории или, по крайней мере, представлениям об этих фактах. Это соответствие вызывает сомнения даже у сторонников общей концепции А. Подлазова. Они полагают, что «имеющиеся данные противоречат вытекающему из модели А.В. Подлазова выводу о том, что гиперболический рост населения Земли на всем его протяжении сопровождался снижением смертности» [Коротаев и соавт. 2007 $: 173]$.

Цитируемые авторы убеждены, что «в течение нескольких тысячелетий неолитической революции и последующей интенсификации производящей экономики гиперболический рост населения Земли сопровождался не уменьшением, а увеличением смертности и сокращением средней продолжительности жизни», так как переход к производящему хозяйству «неизбежно вел к ухудшению условий человеческого существования», в частности рациона питания из-за «увеличения в диете людей крайне ограниченного числа культур (наиболее продуктивных и калорийных, а значит,

4 Вообще говоря, в математической модели можно было бы использовать и другие показатели - неттокоэффициент воспроизводства (коэффициент Кучинского) или истинный коэффициент естественного прироста (коэффициент Лотки). 
содержащих из питательных веществ мало чего, кроме углеводов) в ущерб всему остальному». По мнению Коротаева и соавторов, в эти же самые тысячелетия гиперболический рост населения шел не за счет снижения смертности, а за счет увеличения рождаемости, так как переход к производящему хозяйству сопровождался «радикальным увеличением уровня оседлости, ростом содержания углеводов в диете, появлением аналогов детского питания (разного рода каш), позволявших сократить срок кормления грудью с соответствующим сокращением периода между родами и т.п.» [Коротаев и соавт. 2007 : 174].

Вопрос о понижении или повышении смертности в неолите не нов, но он никогда не обсуждался в демографической литературе в контексте гиперболического роста населения и совершенно не требует этого контекста. Он всегда связан с вопросом о причинах резкого ускорения роста населения в результате неолитической революции, т.е. об уже упоминавшемся неолитическом демографическом взрыве.

Хотя едва ли можно сомневаться в том, что рост населения Земли, пусть и очень медленный, шел и в палеолите, нет никаких указаний на то, что он был обусловлен снижением смертности. Это означало бы снижение зависимости роста населения от плотности, но такая зависимость не ослабевала, палеолитические охотники и собирателя могли жить только при очень низкой плотности населения. Поэтому рост населения мог идти лишь за счет постепенного расширения ойкумены, чему способствовало и улучшение климата, связанное с окончанием последней ледниковой эпохи. «Когда ледяные шапки, наконец, растаяли, человеческое население, по-видимому, приближалось к отметке 4 миллиона. Это было большим успехом, но прирост был достигнут почти полностью за счет расширения области его расселения (extension of range), и теперь этого процесс подошел к своему пределу. Дальнейший рост был возможен только при повышении плотности» [McEvedy and Jones 1979: 14-15].

Неолитическая революция позволила преодолеть палеолитический барьер плотности населения, благодаря чему и начался стремительный - разумеется, по меркам той эпохи - демографический рост. С объяснением механизма этого роста и связан давний спор о том, за счет чего произошел неолитический демографический взрыв: за счет снижения смертности или за счет повышения рождаемости.

Существует обширная и довольно давняя литература, посвященная «неолитическому кризису смертности» [Caldwell, Caldwell 2003], еще в моей книге 1982 года я упоминал о «представлениях некоторых авторов, согласно которым переход к производящей экономике имел своим следствием не снижение, а повышение смертности» [Вишневский 1982: 93]. Доводы, якобы подтверждающие версию такого повышения, (они звучат и в приведенных выше словах Коротаева и соавторов), не казались мне убедительным тогда и не кажутся убедительными сейчас.

Изучение смертности доживших до нашего времени палеолитических собирателей указывает как на то, что их кривая дожития сильно отличалась от соответствующей кривой даже ближайшего предшественника человека шимпанзе, так и на то, что в большей степени отличия определялись выигрышем, полученным взрослыми людьми. Вероятность смерти в 
детстве была в 3 раза ниже, чем у шимпанзе, а к возрасту 45 лет разрыв становится восьмикратным [Gurven, Kaplan 2007: 343].

В то же время можно привести аргументы в пользу того, что неолитическая революция должна была иметь своим следствием принципиальное изменение кривой дожития и рост продолжительности жизни. Переход к оседлости, возникновение семьи, появление собственности, принципа наследования и другие подобные изменения не могли не привести к усилению заботы о потомстве и повышению вероятности выживания детей. Отсюда - неизбежное улучшение кривой дожития на участке младших возрастов, что существенно влияет на среднюю продолжительность жизни. Это также подтверждается имеющимся эмпирическим материалом, чаще всего (хотя и не всегда) «исследования, посвященные изучению влияния оседлости на смертность, показывают общее снижение детской смертности», причем одновременно может наблюдаться и повышение рождаемости [Gurven, Kaplan 2007: 339].

Повышение рождаемости в результате неолитической революции вполне вероятно по тем же причинам, по которым должна была снижаться детская смертность, т.е. благодаря многоплановым изменениям в условиях жизни и быта людей, их здоровье и т.п. Поэтому неолитический демографический взрыв мог быть - и, скорее всего, был - результатом как снижения смертности, так и повышения рождаемости.

По оценкам, население Древнего Египта в 3000 г. до н.э. приближалось к 1 млн человек, а за 150 лет до начала нашей эры - к 5 млн человек [Butzer 1976: 83], т.е. было примерно таким, как все население Земли за 8 тыс. лет до этого. Такой колоссальный рост населения, пусть даже и локального, плохо увязывается с гипотезой повышения смертности при переходе к сельскохозяйственной экономике и оседлости, но вполне совместим с гипотезой одновременного снижения смертности и роста рождаемости. В то же время нетрудно предположить, что, пережив период стремительного роста, население Египта подошло к новому барьеру плотности, и должны были включиться новые тормоза роста, иные, чем те, с какими сталкивались люди в палеолите. В этом смысле нет ничего неожиданного, например, в недавнем открытии генетиков, установивших, что история эпидемий чумы намного дольше, чем думали прежде, и восходит ко временам Древнего Египта. «Эти ранние вспышки чумы, возможно, несут ответственность за сокращение населения в конце 4 и в начале 3 тысячелетий до н.э.» [Rasmussen et al., 2015: 577].

И это было не единственное препятствие, возникшее на пути успеха «жизнесберегающих технологий», которым придает столь важное значение А. Подлазов. Еще одна опасность, усиливающаяся с ростом численности и плотности населения, - это опасность массового голода, обусловленного не плотностью населения самой по себе, а беззащитностью крупных скоплений людей перед лицом стихийных бедствий. Библейский рассказ о семи годах голода «в земле Египетской» и «по всей земле» (Быт., 41: 54- 57), имеет, по-видимому, реальные основания. Сохранилась надгробная надпись, относящаяся к IV тысячелетию до н.э. «Семь лет ... Нил не выходит из берегов. Пусты поля, не зреют урожаи, нет никакой другой пищи... Распахнуты кладовые, но вместо припасов в них один воздух. Исчерпано все» [Дэвис 1996]. С тех пор подобные вспышки голода повторялись 
бесчисленное количество раз - и в Египте, и во всех других районах мира, где господствовала аграрная экономика и судьба людей зависела от судьбы урожая.

Наконец, именно здесь уместно было бы вспомнить о «принципе Олли», о котором упоминает и А. Подлазов. Этот принцип требует не максимальной, как можно понять его изложение А. Подлазовым, а оптимальной численности популяции. Согласно принципу Олли, с ростом численности и плотности групп не только повышается их способность к выживанию, но одновременно усиливается и конкуренция между группами. Это относится к дикой природе, но в переводе на человеческий язык это означает повышение вероятности военных столкновений. При этом, как справедливо отмечает А. Подлазов в одной из своих более ранних публикаций, «любая технология, которая может спасать жизни, может и отнимать их» [Подлазов 2000], что и подтверждается растущей кровопролитностью войн.

Все эти апокалиптические опасности появились не тогда, когда разворачивалась неолитическая революция, а тогда, когда она завершилась и принесла свои плоды. «Обычная» смертность, наблюдавшаяся в периоды, когда не было ее катастрофических подъемов, немного снизилась, но все равно оставалась очень высокой, средняя продолжительность жизни редко превышала 30 лет, далеко не всегда достигала этой отметки и на протяжении тысячелетий практически не росла. Тем не менее и достигнутого небольшого снижения смертности оказалось достаточно, чтобы повысить реализацию биотического потенциала человека. Там, где это произошло, население резко увеличилось и, по-видимому, достигло нового барьера плотности, что привело к включению новых (катастрофических) тормозов и значительному замедлению, а, может быть, и прекращению демографического роста. Для того, чтобы преодолеть этот барьер, понадобился следующий прорыв, который и был совершен уже в Новое время и привел к современной демографической революции.

Таким образом, представление о человеческой истории как непрерывном поступательном развитии в использовании жизнесберегающих технологий вызывает сомнения прежде всего с точки зрения соответствия этих представлений наблюдаемым фактам. Но оно уязвимо и с точки зрения общеметодологических представлений, лежащих в основе взглядов А. Подлазова и его единомышленников.

\section{РОСТ ЧИСЛЕННОСТИ ИЛИ ПОДДЕРЖАНИЕ РАВНОВЕСИЯ?}

Концепция жизнесберегающих технологий занимает центральное место в круге идей А. Подлазова. Она получила высокую оценку среди сторонников гипотезы гиперболического роста, считающих его подход важным вкладом в развитие теоретической демографии. «Введенное им понятие жизнесберегающих технологий открывает перспективы для введения демографически ориентированной шкалы для различных и плохо сопоставимых технологических инноваций» [Коротаев и соавт. 2007а: 173].

Под жизнесберегающими технологиями А. Подлазов понимает «любые знания и навыки, которые могут быть использованы для спасения человека от смерти или продления его жизни», а общий уровень технологического развития оценивает «по производимому 
эффекту, определяемому долей людей, которых удается спасти от смерти в единицу времени». По его мнению, в теоретической демографии жизнесберегающие технологии могут играть роль «естественного скаляризатора», сводящего все виды человеческой деятельности к количеству сохраненных жизней. Что же касается демографического роста, то он «обусловлен расширением технологической ниши человечества вследствие развития им жизнесберегающих технологий, мерой которого служит обусловленное ими сокращение коэффициента смертности». Отсюда и ускорение роста населения, поскольку «единственная задача любого биологического вида - преумножать свою численность» [45].

Этот высказанный вскользь постулат «единственной задачи биологического вида», играющий важную роль в системе рассуждений А. Подлазова, далеко не бесспорен. Обычно считается, что если вообще можно говорить о цели живой природы, то «в качестве такой цели... можно принять стремление к самосохранению» [Ляпунов 1970: 185]. Достижение же этой цели биосистемой связывается отнюдь не с безудержным количественным ростом, а с характером ее взаимодействия со средой, со способностью обеспечить свою жизнь необходимыми для этого средствами и защитить выполняемые жизненные функции от неблагоприятных внешних воздействий. «Эти две стороны сохранительных свойств тесно связаны между собой и лежат в основе всех классических представлений о самосохранении биосистем» [Новосельцев 1978: 32].

Биосистема, которая, как правило, рассматривается, когда речь идет о динамике численности, это не вид, а популяция. Численность вида в дикой природе может увеличиваться за счет расселения и умножения числа популяций, но этого может и не происходить, никакого специального механизма, требующего такого роста, не существует, космополитические виды довольно редки, большинство видов не выходят за пределы своих ареалов. Что касается популяций, то для них характерно, скорее, относительное постоянство численности, прокладывающее себе путь через непрерывные колебательные отклонения от уровня равновесия, а отнюдь не ее преумножение.

Биотический потенциал любого вида способен обеспечить огромный рост численности популяции в нелимитированной среде, но нелимитированной среды в природе, как правило, не бывает. В обычных условиях устойчивых экосистем высокая плодовитость нужна не для того, чтобы популяция выросла, а для того, чтобы она не вымерла, и это важно не только для той или иной популяции, но и для экосистемы в целом. Низкая же смертность вообще не нужна природе. «Преждевременная» (до вступления в стадию размножения) смертность избыточного потомства - главный механизм, приводящий динамику численности популяций в соответствие с интересами целостности более высокого порядка, т.е. с интересами экосистемы. Такая смертность - огромная растрата энергии, с точки зрения популяции, способной к очень быстрому размножению, но отнюдь не с точки зрения экосистемы, существующей только потому, что ее пронизывают трофические цепи, состоящие из обреченного на гибель подавляющего большинства произведенных на свет организмов. «Задача» же любого биологического вида - не преумножение численности, а выживание вместе с экосистемой, в которую он включен. Эта задача решается разными видами с разной степенью эффективности, если под эффективностью понимать долю выживающего и обеспечивающего сохранение вида потомства. 
По мере продвижения по эволюционной лестнице, у видов, находящихся на верхних уровнях пищевых сетей, появляется возможность менее расточительного размножения. Обычные потери от смертности у млекопитающих несопоставимо меньше, чем у насекомых или рыб, а это делает возможной и намного более низкую рождаемость. Более того, у теплокровных появляются рефлекторные реакции, которые позволяют в какой-то степени смягчать колебания численности не только ценой роста смертности. Некоторые виды способны предвосхищать нарушение экологического равновесия за счет роста популяции и несколько сдерживать этот рост, сокращая производство потомства, - у птиц уменьшается число яиц в кладке, у грызунов рассасываются беременности или включаются другие механизмы, снижающие рождаемость, и т.п. В итоге та часть жизнедеятельности вида, которая связана с размножением популяций, становится все менее затратной, все более эффективной, благодаря чему расширяются функциональные и морфологические возможности организмов, их жизнедеятельность становится все более сложной и разносторонней.

История эволюции видов - это история непрерывного повышения такой эффективности, движения от расточительной $\boldsymbol{r}$-стратегии размножения ко все более экономной $\boldsymbol{K}$-стратегии. Каждый шаг этого движения знаменует собой изменение в условиях взаимодействия вида со внешней средой. Но каждое такое изменение говорит не об ослаблении зависимости вида от среды, а о росте его способности решать все ту же навязываемую средой задачу - поддержание экологического равновесия - меньшей ценой.

Впрочем, иногда может показаться, что, в конце концов, изменяется и сама задача. Как замечают И. Пригожин и И. Стенгерс, «повышение $\boldsymbol{K}$ в рамках логистической модели влечет за собой последствия, выходящие за круг явлений, описываемых логистическими уравнениями» [Пригожин, Стенгерс 1986: 267]. На первый взгляд, это соображение созвучно идее о независимости роста человеческих популяций от давления среды, которое «пригибает» логистическую кривую по мере еe приближения к потолку несущей способности. Ведь в этом, собственно, и заключается принцип «демографического императива» («рост населения определяется внутренними свойствами системы, а не внешними факторами»). Но эти «внутренние свойства» И. Пригожин и И. Стенгерс отнюдь не отождествляют с численностью популяции. Ограничения логистической модели они видят в том, что с развитием $\boldsymbol{K}$-стратегий «другие факторы, помимо численности индивидов в популяции, становятся все более существенными, и логистическое уравнение, измеряющее успех по числу индивидов, все хуже отражает истинное положение дел» [Пригожин, Стенгерс 1986: 267]. Не предполагают они, судя по всему, и освобождения роста популяций $\boldsymbol{K}$-стратегов от зависимости от внешней среды, поскольку говорят, что «логистические уравнения наиболее пригодны, когда критическим измерением является рост популяции», но это лишь «приближение, достоверность которого зависит от связей, наложенных на популяцию, от оказываемого на нее давления и от стратегии, избираемой популяцией для того, чтобы противодействовать вмешательству извне» [Пригожин, Стенгерс 1986: 266]. 
В какой мере эти рассуждения, даже если они и справедливы в отношении животных, применимы к человеку? Ведь вольно или невольно, в явной или неявной форме, концепция гиперболического роста населения включает в себя противопоставление закономерностей динамики численности популяций в мире природы и в мире людей. Понятно, что это не одно и то же, но в чем заключаются различия?

В целом можно считать общепризнанным, что в природе всегда существуют системные механизмы, контролирующие рост численности популяций и, несмотря на ее постоянные отклонения от уровня равновесия, той или иной ценой возвращающие ее к этому уровню. Иными словами, природа, как в актуальном, так и в эволюционном плане, неизменно демонстрирует заботу о поддержании баланса «прихода» и «расхода». Движение по эволюционной лестнице меняет эффективность механизмов поддержания этого баланса, но не отменяет необходимости его соблюдения. В эволюционной перспективе ответом на сокращение «расхода» всегда служит соответствующее сокращение «прихода», при этом никак нельзя утверждать, что более успешные виды отличаются большей численностью.

Еще одно наблюдение, которое можно сделать, заключается в том, что все изменения начинаются с уменьшения «расхода», поскольку на эволюционном пути остаются более приспособленные, т.е. те, кто лучше выживают. При желании, можно было бы, пусть и метафорически, свести всю дочеловеческую историю жизни на Земле к непрерывному совершенствованию жизнесберегающих технологий и даже увидеть в этом смысл эволюции.

Следуя логике природы, кажется естественным предположить, что появление человеческого общества должно было означать и новый шаг в повышении эффективности механизмов, контролирующих размножение популяций людей, - хотя бы потому, что теперь над биологическими регуляторами надстраиваются социальные, обладающие своей высокой эффективностью. И в самом деле, человек, выражаясь словами А. Подлазова, «справляется с этой задачей качественно лучше животных» [45]. Но это совсем не задача преумножения численности, о которой говорит А. Подлазов и которая, по его мнению, дает основания говорить о фундаментальных отличиях динамики численности людей от популяционной динамики других видов. Это все та же задача поддержания равновесия, которое, по аналогии с экологическим равновесием, можно назвать демографическим равновесием, заведомо понимая, что его поддержание требует механизмов, более сложных, чем действующие в природе.

\section{ЧЕЛОВЕК И СРЕДА}

Человечество - это больше, чем биологический вид Homo sapiens. Это такая система, которая, развив внутри себя социальную жизнь, обособилась от природы, возвела границу между собой и природой, ставшей по отношению к ней «внешней средой». Но при этом она не перестала быть открытой системой, существование человечества возможно только при его взаимодействии со внешней средой, при интенсивном обмене с ней веществом, энергией и информацией. Такое взаимодействие не может не накладывать на жизнь 
человечества, в том числе и на его численность, определенных ограничений. В каждый данный момент истории люди живут в лимитированной среде и в этом смысле ничем не отличаются от животных. Разумеется, возникновение социальной жизни создает новые степени свободы. Но «диалог с природой» не прекращается, а кроме того, социальная жизнь порождает и свои ограничения.

Поэтому представляется весьма спорным тезис о «внематериальном демографическом императиве», о «самопричинности» роста населения, который определяется «внутренними свойствами системы, а не внешними факторами», что «дает основания для признания... первостепенной и самодостаточной роли демографии в истории развития человеческого общества» [Коротаев и соавт. 2007а : 162, 165]. Неужели действительно динамика численности населения не зависит ни от каких внешних факторов, ни от какой «среды» - природной или социальной?

Подход А. Подлазова, также исследующего «демографическую динамику всего человечества как целостной системы», но обращающегося к «технологическому императиву», кажется более реалистичным. Он использует представление о «технологической нише» и, насколько можно понять, речь идет о нише, которую человек, расширяя ее благодаря развитию технологий, отвоевывает у природы. Тем самым постулируется «первичность технологических факторов по отношению к демографическим», что и дает основания для замены принципа демографического императива принципом технологического императива, в котором А. Подлазов видит «принципиальную конкретизацию демографического императива» [47]. Но идея о «главенстве», «самодостаточности» демографического начала при этом не исчезает.

Согласно представлениям А. Подлазова в более ранней формулировке, «в наборе переменных, описывающих крупномасштабные социальные, исторические, культурные, экономические и т.п. процессы, численность народонаселения является параметром порядка, т.е. той медленной переменной, к которой подстраиваются все прочие» [Подлазов 2001]. Многократно повторенная в разных публикациях мысль заключается в том, что движущая сила истории ${ }^{5}$ - развитие жизнесберегающих технологий, оно приводит к росту населения, рост населения в свою очередь способствует созданию новых жизнесберегающих технологий - и так без конца до тех пор, пока возможности снижения смертности не исчерпаны. Когда же они исчерпаны, всякое дальнейшее развитие теряет смысл, потому что оказывается исчерпанным «тот единственный ресурс, освоение которого и обеспечивало прогресс цивилизации», и рост населения наталкивается на ограничения, «не связанные с какими-либо материальными факторами» [61].

Мы уже знаем, что, в логике А. Подлазова, «технологический императив» выражается в увеличении «зазора» между неизменной рождаемостью и снижающейся смертностью и в вытекающем из этого ускорении роста населения. Но в этой логике не присутствуют системные реакции обратной связи, тормозящие этот рост, подобно тому, как

\footnotetext{
${ }^{5}$ Вопрос о движущих силах истории выходит за пределы нашей компетенции, но А. Подлазов говорит именно об этом.
} 
это происходит в природе, как будто для человечества нет понятия лимитированной среды. Рождаемость и смертность в его модели - чисто эндогенные переменные.

А. Подлазов упоминает о социокультурных ограничителях рождаемости, которые, казалось бы, как раз и свидетельствуют о неизвестных природе социальных механизмах контроля процесса размножения, тормозящих рост. Но он считает возможным не придавать им большого значения, принимая уровень рождаемости постоянным на всем протяжении человеческой истории. Не видит он системных реакций на рост численности и плотности населения и в подъемах смертности, которая, в его логике, только снижается в ответ на непрерывное развитие жизнесберегающих технологий, как будто он не знает, что в человеческом обществе наряду с жизнесберегающими развиваются и жизнеуничтожающие технологии. Разве в природе существуют аборты, инфантицид, геронтоцид, охота за скальпами, человеческие жертвоприношения, смертная казнь, губительные нашествия и кровопролитные войны? Но, кроме того, и природа не бездействует, и когда человек со своими технологиями нарушает равновесие в природе, то он получает ответ в виде снижения плодородия почвы, исчерпания природных ресурсов или повышения вирулентности болезнетворных бактерий.

Если верить всей накопленной исторической демографией информации, то, вопреки представлениям А. Подлазова, систематического, непрерывного снижения смертности на протяжении всей человеческой истории не было. Могли быть небольшие подъемы и спады, вызванные, например, климатическими колебаниями. Даже незначительное снижение смертности в периоды таких колебаний способно было привести к нарушению равновесия и демографической вспышке, заканчивавшейся эпидемией, войной или кровавым нашествием, когда смерть брала свой реванш. В целом же смертность неизменно оставалась главным регулятором динамики численности населения до самого недавнего времени, хотя люди давно уже осознавали наличие и других регуляторов и, по возможности, их использовали, но лишь как дополнительные механизмы «тонкой настройки».

Хорошей иллюстрацией может служить античная Греция, где в середине I тысячелетия до н.э. сочетание благоприятных условий даже в условиях традиционно высокой смертности привело к быстрому росту населения и была осознана необходимость регулирования этого роста. Одним из механизмов такого регулирования стало отселение в колонии - греки основали несколько сотен колоний на берегах Средиземного и Черного морей. Но им был достаточно хорошо знаком и иногда даже становился предметом обсуждения механизм ограничения рождаемости. Аристотель писал, что должно поставить предел для деторождения, «так, чтобы не рождалось детей сверх какого-либо определенного числа... Если же оставить этот вопрос без внимания, что и бывает в большей части государств, то это неизбежно поведет к обеднению граждан, а бедность - источник возмущений и преступлений» [Аристотель 1984: $1265 \mathrm{a}, \mathrm{b}$ ]. Завоевательные походы ученика Аристотеля Александра Македонского тоже были одним из следствий древнегреческого «демографического взрыва», и едва ли они способствовали снижению смертности. 


\section{ДЕМОГРАФИЧЕСКИЙ ПЕРЕХОД КАК ЕВРОПЕЙСКИЙ ФЕНОМЕН}

Одна из главных целей статьи А. Подлазова - построение модели демографического перехода. Этот переход вначале получил развитие как особый феномен, возникший на определенном этапе развития европейского общества, и кажется естественным рассматривать его, прежде всего, в контексте этого развития. Между тем, как мы уже видели, А. Подлазов и его единомышленники помещают его во всемирно-исторический контекст совсем иного масштаба, в котором даже тысячелетия превращаются в незначительные временные интервалы, которыми можно пренебречь. Как справедливо заметил В. Кононов по поводу астрофизика Себастьяна фон Хорнера, тоже интересовавшегося динамикой населения и верившего в гиперболический закон, с точки зрения астрофизика, занимающегося проблемами внеземного разума, «небольшие» отклонения, имевшие место в истории Земли, и в самом деле не столь существенны в сравнении с общим процессом изменения численности человеческой популяции» [Кононов 2015: 93].

Но все же демографический переход начался именно в Европе, она стала первой лабораторией, в которой реализовался этот исторический феномен, и есть смысл посмотреть, как этот феномен развивался и осмысливался европейским сознанием, тем более что это происходило в совсем недавнее время, о котором, в отличие от нижнего палеолита, имеется достаточно полная информация.

Согласно общепринятым представлениям, Европа стала пионером демографического перехода в результате совершившегося здесь технологического прорыва, в том числе и небывалого прогресса жизнесберегающих технологий. Есть множество объяснений авангардной роли Европы в их развитии, но совсем не ясно, что могут добавить к этим объяснениям закон гиперболического роста, принцип демографического или технологического императива и т.п. Почему этот прорыв произошел в Европе, а, скажем, не в Индии или Китае, где население было примерно таким же, как в Европе, и росло не медленнее, а, значит, с точки зрения декларируемой А. Подлазовым связки между ростом населения и развитием жизнесберегающих технологий, и настоятельность их развития была не меньшей? Действительно ли облаченная в мантию из математических формул модель становится новым словом в системе представлений, которые европейская мысль вырабатывала на протяжении столетий? И если да, то в чем заключается это новое слово? Какие из давно известных истин она отменяет или что к ним добавляет?

Европа на протяжении первых полутора тысяч лет нашей эры почти не знала роста населения. За первое тысячелетие оно вообще не увеличилось, а наметившийся в XI в. рост был прерван эпидемией чумы XIV в. и затем возобновился только в XVII в. (рис. 3) 


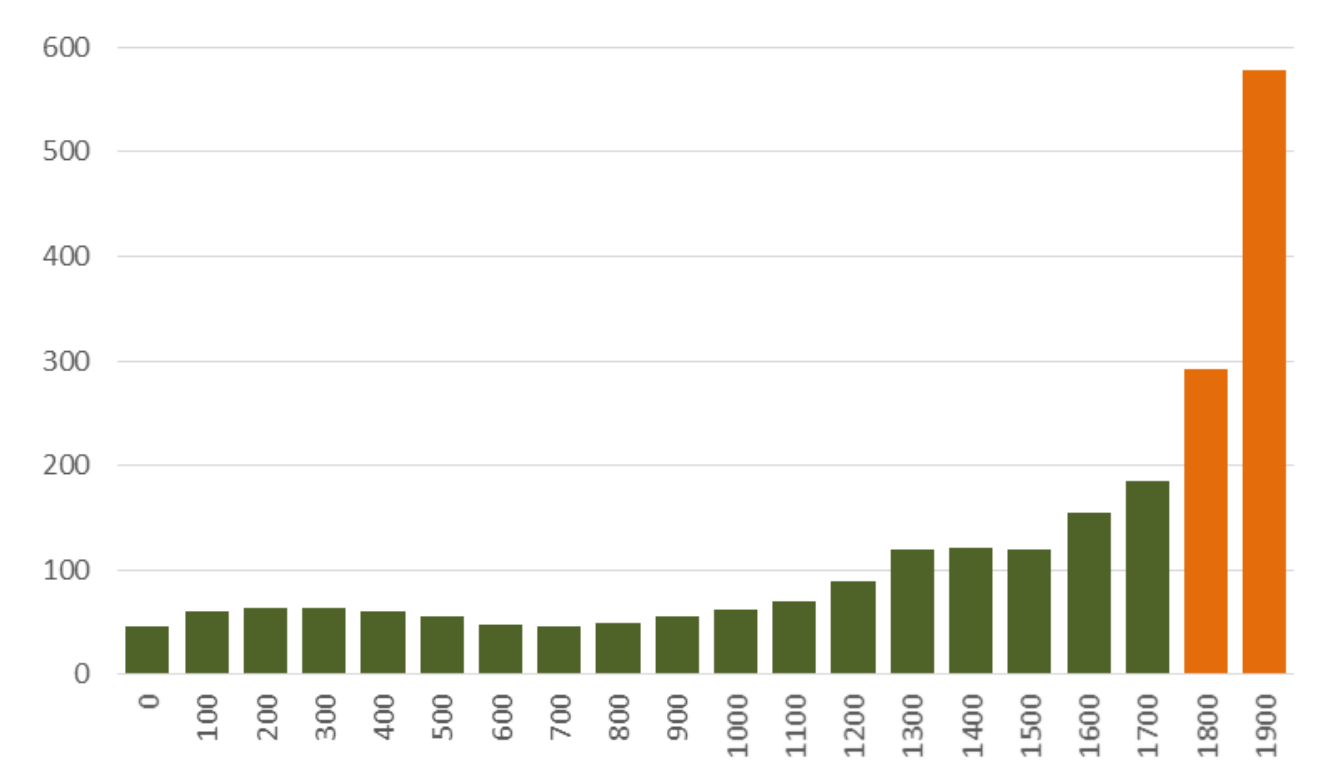

Рисунок 3. Численность населения Европы, млн чел.

Источник: [HYDE site. History Database of the Global Environment].

Этот рост был настолько необычен для европейцев, что им «еще в XVIII в. направление динамики населения было неясно. Так, например, Монтескье, Кенэ и Мирабоотец полагали, что население непрерывно убывает... Лишь в конце XVIII в. факт роста населения стал ясен большинству современников» [Урланис 2007: 63]. (В «Духе законов» есть глава «О том, как обезлюдел мир». В другой главе «Изменение численности населения Европы», говорится, что «население в большинстве европейских стран было многочисленнее, чем в настоящее время» [Монтескье 1955: 517, 526])

Тем не менее, уже в XVIII в. вопрос о росте населения привлек внимание, и появились первые попытки осмыслить это новое явление. В 1741 году, в Берлине, вышла книга немецкого лютеранского пастора Иоганна Петера Зюссмильха под названием «Божественный порядок в изменениях рода человеческого, подтверждаемый его рождениями, смертями и размножением» [Süssmilch 1790-1792] ${ }^{6}$. Считается, что в написании этого трактата принимал участие Эйлер [Паевский 1935: 105].

Для нашей темы важны три положения, содержащиеся в книге Зюсмильха. Вопервых, он исходил из идеи о необходимости поддержания демографического равновесия. «Равновесие - это равновесие числа людей. Перенаселение привело бы ко всеобщей войне» [Süssmilch 1998: 43]. Во-вторых, он утверждал, что поддержание равновесия - это не дело людей, о нем заботится Бог. В-третьих, он считал, что главный механизм, с помощью которого Бог поддерживает равновесие, это смертность.

Рост населения Европы, начиная с XVII в., был обусловлен тем, что европейцы, и в самом деле, упорно развивали жизнесберегающие технологии и, благодаря этому, все более успешно противостояли катастрофическим подъемам смертности от эпидемий, вспышек голода или военных нашествий, что и привело к уменьшению «зазора» между

\footnotetext{
${ }^{6}$ Я пользовался французским переводом [Süssmilch 1998] - АВ.
} 
рождаемостью и смертностью на достаточно протяженных интервалах времени. Но обычная, не катастрофическая смертность оставалась очень высокой. В той же Германии даже в середине XIX в. на первом году жизни умирало 300 из каждой тысячи родившихся детей [Chesnais 1886: 542].

Взгляды Зюсмильха очень четко свидетельствуют об осознании демографических перемен, накопившихся в Европе к XVIII в. Хорошо известно из хроник, и этому же учит видимое нами, - пишет он, что рост населения часто наталкивается на препятствия. «Главные из них, которые и чаще всего дают о себе знать, - это война, мор, а также голод, который в большинстве случаев им сопутствует» [Süssmilch 1998: 43]. Однако он уже не верит, что «указанные препятствия, особенно же войны и чума, это необходимые бедствия, которые Провидение должно использовать, чтобы поддерживать равновесие между людьми, без чего они могут стать бременем друг для друга» [Süssmilch 1998: 43]. Этим «ужасным» препятствиям он противопоставляет другие, которые кажутся ему «безболезненными».

«Размножение это что-то меняющееся, так что Бог может очень легко его замедлить или ускорить в зависимости от состояния мира... Для этого нужно только дать умереть несколько большему числу людей. И это можно сделать совершенно незаметно... Было бы достаточно, чтобы вместо половины умирало $2 / 3$ или $3 / 5$ или 4/7 и т.д. детей, чтобы размножение сильно замедлилось. И кто же усомнится, что Божественное Провидение изберет столь безболезненный путь, а не ужасное бедствие чумы, если оно захочет предотвратить чрезмерное умножение массы людей? Подобно тому как Бог может легко ускорить размножение, давая больше жизненной силы детям, чтобы они не умирали в таком количестве и так быстро, он может столь же легко замедлить его, позволяя умирать большему их числу» [Süssmilch 1998: 100].

Трактат Зюсмильха увидел свет в 1741 г. Новые, прорывные, жизнесбрегающие технологии еще только на старте, первый настоящий прорыв можно условно датировать 1798 годом - годом публикации Эдвардом Дженнером «Исследования причин и действия коровьей оспы», положившего начало принципу вакцинации. И по необыкновенному историческому совпадению в том же году увидит свет провидческое сочинение Томаса Роберта Мальтуса «Опыт о законе народонаселения». Главный посыл этого сочинения: надо сменить регулятор.

Э. Дженнеру пришлось опубликовать его исследование в виде отдельной брошюры за свой счет, поскольку Лондонское королевское общество решило «не рисковать своей репутацией представлением учёному органу всего, что выглядит таким расходящимся с установившимся знанием». Но все же открытие Дженнера получило признание достаточно быстро. Послание Мальтуса не оценено, кажется, до сих пор.

Хотя считается, что все, о чем говорил Мальтус, хорошо известно, напомним в двух словах некоторые высказанные им положения.

Согласно Мальтусу, во всех человеческих обществах размножение населения наталкивается на препятствия, удерживающие численность населения на уровне его 
средств существования. Эти препятствия могут действовать, либо предупреждая рост населения, либо сокращая его по мере чрезмерного возрастания. Первые Мальтус называет предупредительными препятствиями, вторые - разрушительными. В природе действуют только разрушительные препятствия «к безграничному размножению лишенных разума растений и животных», предупредительные же препятствия «свойственны человеку и заключаются в способности, отличающей его от животных, - способности предвидеть и оценивать отдаленные последствия» [Мальтус 1993: 15]. К разрушительным относятся «все причины, стремящиеся каким бы то ни было образом... сократить естественную продолжительность человеческой жизни» [Там же: 15]. Если средства существования не допускают быстрого возрастания населения, «то неизбежно должно произойти одно из двух: или увеличение смертности от какой-либо иной причины, или уменьшение относительного числа рождений». Мальтус высказывается в пользу того, «чтобы произошло последнее» [Там же: 113].

В своих рассуждениях Мальтус не мог выйти за рамки своей эпохи, этого не позволяли ни уровень развития европейского общества XVIII в., ни накопленный к этому времени объем знаний. «Закон народонаселения» у Мальтуса вневременной, он не связывает его ни с какими историческими переменами. Но сейчас-то видно, что интерес Мальтуса к проблеме народонаселения был продиктован именно переменами. В конце XVIII в. назревавший несколько столетий европейский демографический переход вступал в свою активную фазу, и Мальтус был первым, кто почти интуитивно откликнулся на этот небывалый в истории феномен, попытался его осмыслить и сделал это выдающимся образом. Я не говорю сейчас о политических или идеологических аспектах взглядов Мальтуса, которые больше известны в изложении его неблагожелательных толкователей. Но если говорить о демографической логике его рассуждений, то никто из его критиков, среди которых были и крупные фигуры, и даже все они вместе, не могут сравниться с ним по числу последователей, большинство из которых, впрочем, даже и не знает, что следуют по пути, указанному Мальтусом.

Мальтуса отделял от Зюсмильха период примерно в полстолетия, они принадлежали к одной общеевропейской интеллектуальной традиции, оба были протестантскими священниками. В их взглядах были и общие черты, и различия, но в одном пункте их взгляды не совпадают разительно. Речь идет об отношении к преждевременной смертности как регулятору демографической динамики.

Мальтус, так же, как и Зюсмильх, понимал, что Европа уже не испытывает катастрофических подъемов смертности, писал о «постепенном ослаблении, можно сказать даже совершенном прекращении чумы, так часто посещавшей Европу в продолжение семнадцатого и в начале восемнадцатого века», о том, что «в Англии ... улучшились города, эпидемии стали менее часты, и привычка к чистоплотности сделалась всеобщей» [Там же: 105]. Но при этом он, так же, как и Зюсмильх (но в отличие от Подлазова), не считал, что новые «жизнесберегающие технологии» приводят к увеличению продолжительности жизни. Мне кажется, что, занимая такую позицию, он вступал в противоречие с самим собой, но иначе он не мог бы настаивать на существовании универсального вневременного «закона народонаселения». 
«Средняя продолжительность человеческой жизни, несомненно, может несколько удлиниться под влиянием благоприятных для того условий, но также несомненно и то, что в течение всего периода, относительно которого мы имеем достоверные исторические свидетельства, не произошло никакого увеличения в естественной продолжительности человеческой жизни». «В пользу предположения об увеличении продолжительности человеческой жизни мы не находим ни одного постоянного, достоверного признака с момента сотворения человека до настоящего времени» [Мальтус 1993: 25-26].

Таким образом, если вывести за скобки катастрофические подъемы смертности, что делали как Зюсмильх, так и Мальтус, то они сходились во мнении, что исторической динамики смертности не существовало. Расходились же они в том, что Зюсмильх считал преждевременную смертность достаточным и правомерным регулятором роста численности населения, а Мальтус - недостаточным и нежелательным.

Отвечая критикам, которые «утверждают, что естественные препятствия к размножению населения совершенно достаточны для того, чтобы всегда сдерживать его в необходимых границах, а потому нет надобности в установлении еще иных препятствий» и даже требуют представить «доказательства в подтверждение недостаточности тех препятствий, которые действуют в настоящее время», Мальтус замечает, что «в глазах рассудительного человека препятствие, находящееся в зависимости от благоразумия, не менее естественно, чем нищета или преждевременная смерть, которым мои противники, повидимому, отдают предпочтение» [Там же: 113-114]. Под «препятствиями, находящимися в зависимости от благоразумия» он понимал снижение рождаемости.

Если бы не статическая картина мира, каким он виделся Мальтусу (никакого увеличении продолжительности человеческой жизни с момента сотворения человека), его можно было бы с полным правом назвать отцом концепции демографического перехода. Этого нельзя сделать, потому что исторической динамики, «перехода», он как раз и не видел. Но мы вправе признать его праотцом этой концепции, потому что именно он был тем человеком, который первым произнес нужное слово в нужное время. И сегодня мы будем очень недалеки от того, к чему призывал Мальтус, если скажем, что демографический переход - это смена регулятора демографической динамики, переход от поддержания демографического равновесия в основном посредством механизма неуправляемой смертности к его поддержанию в основном посредством механизма управляемой рождаемости. Меняется механизм достижения цели, но не сама цель демографическое равновесие.

В свое время я пытался пояснить эту мысль, прибегнув к аналогии с фазовым переходом и представив на фазовой диаграмме траекторию изменения нетто-коэффициента воспроизводства населения - ключевой характеристики его динамики, отражающей итог взаимодействия рождаемости и смертности (С. Капица воспроизвел эти диаграммы в своих книгах). В начальной фазе перехода нетто-коэффициент воспроизводства колеблется вокруг некоторой точки-аттрактора, соответствующей положению равновесия. С изменением внешних условий сила аттрактора уменьшается, на некоторое время система теряет свою устойчивость и происходит сдвиг фазовых траекторий. Но рано или поздно 
фазовые траектории стягиваются к прежней точке аттрактора, и устойчивость поведения системы восстанавливается [Vishnevsky 1991: 265].

А. Коротаев с соавторами также обращаются к образу фазового перехода, но трактуют его по-иному. У них «это - фазовый переход на новый, не типичный для всей прежней истории, режим развития» [Коротаев и соавторы 2007ª. 164]. То, что я понимаю как возврат к прежнему равновесию, в их понимании - уникальная аномалия, небывалое отклонение от неизменно действовавшего до недавних пор гиперболического закона. Об этом же говорит и А. Подлазов, подчеркивая, что «в результате демографического перехода происходит замедление роста населения относительно [гиперболического] закона».

Демографический переход в Европе (сейчас вернее говорить о развитых странах, относящихся, за некоторыми исключениями, к европейской культуре) завершен в том смысле, что роль регулятора динамики численности населения полностью перешла к рождаемости. Европа пережила свой демографический взрыв в XIX в., и соотношение рождаемости и смертности снова приблизилось к уровню равновесия. Если исключить вероятность крупных катаклизмов, то близость к этому уровню, скорее всего, будет сохраняться, как раз и свидетельствуя о возвращении к прежнему аттрактору. Так, во всяком случае, предполагают имеющиеся прогнозы, основанные на «классическом» представлении о демографическом переходе (рис. 4).

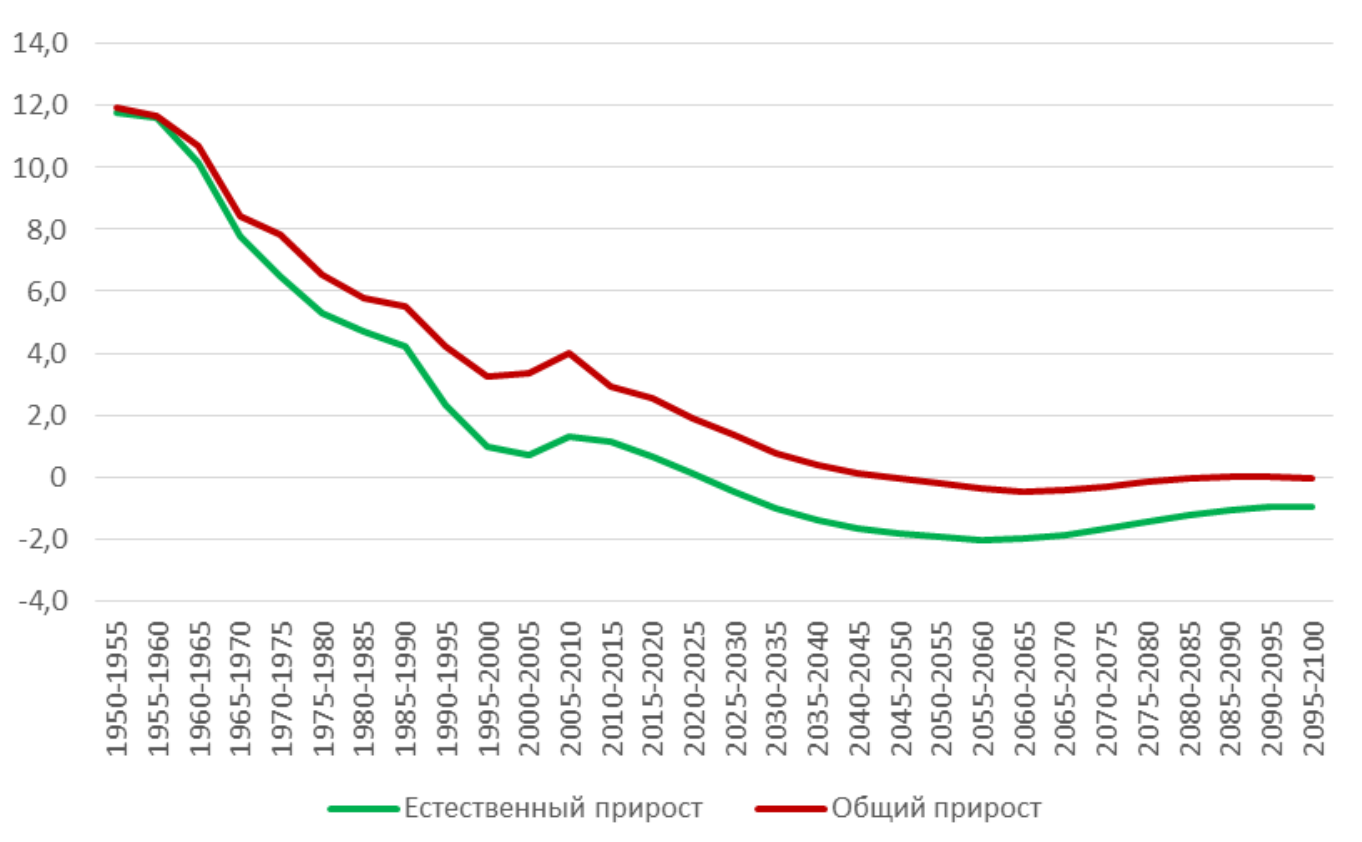

\section{Рисунок 4. Годовой прирост населения развитых стран - фактический и по среднему варианту прогноза ООН до 2100 г.}

Источник: [WPP 2017, Files POP/2, POP/3]

Правда, представленный на рис. 4 прогноз предполагает длительное сохранение отрицательных значений коэффициента естественного прироста в постпереходных странах, что кажется несовместимым с идеей восстановления равновесия. Предсказываемая прогнозом стабилизация численности населения в этих странах возможна только за счет притока мигрантов. Однако в этом нет ничего нового. Миграция (которую, как мы знаем, 
не принимает во внимание А. Подлазов) всегда была третьим компонентом демографического баланса, и в этом случае действительно можно говорить обо всей истории человечества от нижнего палеолита до наших дней. Но такое развитие событий выводит нас за пределы постпереходных стран и заставляет взглянуть на то, что происходит за их пределами - миграционный приток возможен только оттуда.

\section{ДЕМОГРАФИЧЕСКИЙ ПЕРЕХОД КАК ГЛОБАЛЬНЫЙ ФЕНОМЕН}

Если в развитых странах демографический переход в основном завершен, то в развивающихся, а это - большинство современного человечества - он в самом разгаре. Не удивительно поэтому, что А. Подлазов и другие сторонники универсального гиперболического закона, пытаясь вывести свою модель перехода из этого закона, обращаются к демографическому переходу уже как к глобальному феномену. Европейский опыт для них не так уж важен хотя бы потому, что, по словам А. Подлазова, в отличие от традиционной демографии, «глобальная демография имеет дело не с территориями или группами, а исследует демографическую динамику всего человечества как целостной системы» [39]. Их беспокоит то, что «механизм глобального демографического перехода вплоть до самого последнего времени не был описан математически с учетом предыдущей динамики роста населения мира» [Коротаев и соавт. 2007ª: 171].

Необходимость и плодотворность учета предыдущей динамики подкрепляется постоянными ссылками на работы С. Капицы, но особенно часто - на статью Х. фон Фёрстера, П. Мора и Л. Амиота «Судный день: пятница, 13 ноября, 2026 год нашей эры»] [Foerster, Mora, Amiot 1960]. (13 ноября - день рождения Фёрстера. Судный день приурочен к его 115-летию). А. Коротаев и соавторы подчеркивают, что статья о Судном дне была опубликована, «когда гиперболическая зависимость выражалась наиболее явно», с восхищением пишут о том, что авторы этой статьи «предвидели снижение темпов роста и фактическое изменение закона роста человечества, действовавшего на протяжении всей истории» и писали о необходимости снижения рождаемости во избежание серьезных катаклизмов. «Курьезно, но уже через 3 года прогноз начал стремительно сбываться и рост разрыва между смертностью и рождаемостью сменился резким сокращением» [Коротаев и соавторы 2007 : 160$]$.

На самом деле, ничего курьезного в этом нет, в 1960 г. подобные предвидения были уже общим местом. Снижение небывало высоких, ранее никогда не встречавшихся в истории высоких темпов роста, после того, как демографический взрыв в 1965-1970 гг. прошел свою верхнюю точку, было вполне ожидаемым, предсказанным теоретиками демографического перехода, которые также с предельной ясностью объясняли причины и механизм этого снижения (хотя, если верить А. Подлазову, они не сформулировали даже «первые принципы»). Об этом, как упоминалось выше, еще в 1945 г. говорил К. Дэвис, и тогда же Ф. Ноутстайн писал об «ускоренном росте в период с 1940 по 1970 год, но резком сокращении после этой даты», как и о том, что для этого должна снизиться рождаемость [Notestein 1945: 57]. Ноутстайн недооценил скорость и масштабы роста, но если говорить о динамике темпов роста, то их увеличение прекратилось и сменилось их падением в 
точности в соответствии с его предсказанием. Здесь важна даже не столько хронологическая точность, сколько содержательная логика предсказания, понимание сути происходящего. Поэтому утверждение А. Подлазова о том, что «мы знаем, почему прекращается рост, но не знаем, как именно это происходит», и что для того, чтобы это узнать, «новая модель должна сводиться к старой в фазе роста» [51], едва ли выглядит убедительным.

Никакого обращения к далекой истории для понимания современного глобального демографического перехода и для предсказания его завершения не требуется, весь мир просто повторяет тот путь, который проделала Европа в совсем недавнем прошлом. Это признает, в частности, и один из главных адептов гиперболического закона А. Коротаев, позиция которого, правда, не отличается большой последовательностью. В ряде случаев он совершенно справедливо указывает на то, что демографический переход стал глобальным только после Второй мировой войны в результате всемирной «диффузии медицинских технологий, приводивших к резкому снижению младенческой и детской смертности» [Коротаев 2015: 155]. По существу, это означает, что европейский переход был эндогенным, пионерным, а всемирный - догоняющим, «тиражирующим» европейские достижения. Забыв о «гиперболическом законе», в полном соответствии с «классическими» представлениями теории демографического перехода, А. Коротаев рассматривает ускорение роста населения - вначале на Западе, а затем и во всем мире - как первую фазу демографического перехода, вызванную снижением смертности, а последующее замедление, обусловленное снижением рождаемости, как его вторую фазу [Коротаев 2015: 154-157]. При этом он оказывается в русле «классических» представлений о демографическом переходе, лишенных экзотики гиперболического закона. В цитируемой статье этот закон даже не упоминается, не нужно и обращение к «предыдущей динамике роста населения мира», описание демографического перехода от этого ничуть не страдает и даже становится более точным.

Другое дело - трактовка А. Коротаевым различий эндогенного («западного») и догоняющего (в развивающихся странах) демографического перехода. С ней согласиться трудно.

В чем он видит эти различия? «В странах Запада в XIX в. в качестве независимой переменной выступал, скорее всего ВВП на душу населения, чей рост в конечном счете вел к снижению смертности и ускорению темпов роста населения», тогда как «в послевоенном Третьем мире в качестве независимой переменной выступал темп роста населения, чье ускорение тормозило рост ВВП на душу населения» [Коротаев 2015: 155].

Мне кажется, что в первой части этого рассуждения пропущено промежуточное звено: к снижению смертности в странах Запада вел не рост ВВП сам по себе, а обусловленное им развитие уже не раз упоминавшихся жизнесберегающих технологий. Следствием снижения смертности становится ускорение роста населения, а затем и снижение рождаемости как системная реакция на то, что рост упирается в потолок, прекращение роста населения и восстановление нарушенного равновесия.

В развивающихся странах новые жизнесберегающие технологии появляются по другой причине, в отличие от Запада, они получают их готовыми. Но коль скоро они 
появились, события развиваются в соответствии с той же логикой, что и в первом случае: снижение смертности приводит к ускорению роста населения, оно упирается в потолок, роль регулятора переходит к рождаемости, и она снижается.

Таким образом, несмотря на множество конкретных различий, фундаментальная основа в обоих случаях одинакова. Генезис демографического перехода в Европе XIX в. и в послевоенном Третьем мире был разным, но суть одна: сначала снижается смертность, утрачивая роль системного регулятора численности населения, а в ответ снижается рождаемость, принимающая эту роль на себя.

Для демографического перехода, естественным образом складывающегося из нескольких этапов, характерна неизбежная в таких случаях асинхронность. Необычное (а не обычное, как полагает А. Подлазов) снижение смертности служит спусковым крючком, запускающим изменения в системе, на которые она реагирует с запаздыванием.

В случае европейского эндогенного перехода поиски адекватной реакции на снижение смертности заняли немалое время, были опробованы разные варианты ответа, в частности, такие, как увеличение миграции (миграционный переход), распространение поздней брачности или даже безбрачия, и только на поздних стадиях перехода утвердился «неомальтузианский» ответ - непосредственный индивидуальный контроль рождаемости. У европейцев был определенный запас времени, потому что снижение смертности происходило постепенно, но все же и Европа не избежала своего демографического взрыва.

Догоняющий демографический переход в Третьем мире требует иных, гораздо более сжатых сроков, ибо здесь он основан на применении результатов европейского технологического и социального опыта, полученных в готовом виде. Хотя адаптация европейских достижений традиционалистскими обществами тоже происходит не сразу и не безболезненно, счет времени теперь идет не на столетия, а на десятилетия. Этому способствует и острота ситуации: мировой демографический взрыв приобретает гигантские масштабы, и запаздывание ответных реакций глобальной демографической системы становится смертельно опасным для всей человеческой цивилизации. Идея «Судного дня» носится в воздухе, так что его появление в названии статьи фон Фёрстера и соавторов вполне объяснимо.

\section{ЗАКЛЮЧЕНИЕ}

Современное научное знание не может развиваться, замыкаясь в рамках какой-то одной дисциплины, поэтому вторжение математики в демографию - это отнюдь не агрессия, а совершенно естественное проявление междисциплинарного взаимодействия, так же, как, скажем, обращение к физическим аналогиям при осмыслении социальных, в том числе и демографических процессов. Но значит ли это, что математика должна заменить демографию? Фрэнк Ноутстайн, автор термина «демографический переход», передавал содержание своей «полусерьезной беседы» с математиком Джоном фон Нейманом, заметившим, что «некоторые исследования Лотки, касающиеся стабильных населений, существенно не отличались от исследований проблем ядерного деления, которые физики 
развивали во время войны, не зная о работах Лотки. Фон Нейман отметил, что ядерная цепная реакция в какой-то степени аналогична реакции роста населения. При делении происходит нечто вроде рождения ядра в конечные интервалы [времени]. Существует «смерть» в нерасщепляемом поглощении, и происходит миграция из рассматриваемой совокупности. Так же, как и при росте населения, существует цепная реакция, когда отношение «дочернего» поколения к «материнскому» превышает единицу, - знакомый демографам чистый коэффициент воспроизводства. Фактически, он предположил, что демографы зря тратили свое время на изучение стабильных возрастных распределений в человеческих популяциях, потому что при ядерном делении поколения приходят гораздо быстрее, и, кроме того, имеется то достоинство, что они не осложнены делением по полу» [Notestein 1963: 247].

Замечание фон Неймана любопытно, но все же его расширительное толкование в том смысле, что демографы зря тратят время, так как потом все равно придет математик и все решит за две минуты, едва ли оправдано. Иногда, напротив, приход математика способен разочаровать демографа, искренне надеявшегося на расширение с его помощью возможностей своего исследования.

Возможно, главная причина такого разочарования - чрезвычайная сложность объекта, с которым приходится иметь дело математику, когда он обращается к изучению человеческого общества. Мне кажутся оправданными предостережения С. Циреля, который, высоко оценивая теорию С. Капицы, все же замечает, что пока «мы не умеем представлять качественные гуманитарные понятия как математические объекты», «практически все сбывшиеся исторические, и в т.ч. демографические, прогнозы (объявленные загодя, а не post factum) были сделаны "гуманитарными" способами», а «примеры успешного математического описания социальных и исторических явлений ограничиваются редкими случаями» [Цирель].

Но немалое значение имеет также фактическое отсутствие декларируемого «синтеза математических методов и предметного знания» [Коротаев и соавт. 2007 ${ }^{\mathrm{b}}$; 7]. Математические формулы могут быть безупречными, но при этом, как минимум, необходимо однозначное понимание сути моделируемого процесса, его «физического смысла», что невозможно без «предметников». В случае с пониманием сути демографического перехода сторонниками закона гиперболического роста такой однозначности нет.

Как мы только что видели, А. Коротаев, в соответствии с «классическими» представлениями, рассматривает две фазы перехода: фазу ускорения роста населения, когда снижение смертности опережает снижение рождаемости, и фазу сокращения населения, когда снижение рождаемости восстанавливает нарушенное равновесие. Такая трактовка существенно отличается от трактовки А. Подлазова, для которого вся история делится на «период роста» - несколько миллионов лет «от нижнего палеолита до возникновения постиндустриального общества», и на демографический переход - несколько последних столетий, если не десятилетий. Демографический переход предстает, таким образом, как уникальное переломное событие на всей тропе эволюции от олдувайского человека до 
наших дней, и смысл этого события заключается в том, что продолжавшееся до его начала увеличение темпов роста населения сменяется их падением.

Подобный взгляд оказывается более или менее общим для многих сторонников «гиперболической гипотезы». Если обычно внимание «предметных» исследователей демографического перехода прежде всего привлекает сопровождающее его невиданное ускорение роста населения, то уже у С. Капицы это «резкий переход от стремительного роста к стабилизированному населению предвидимого будущего» [Капица 1999а: 130]. Сторонники «гиперболической гипотезы» замечают, в первую очередь, именно замедление роста. Им «в глаза бросается стремительное падение темпов роста, произошедшее за последние несколько десятков лет» [Коротаев и соавторы 2007а : 164]. Фаза же предшествующего увеличения темпов трактуется не как часть перехода, а как естественное продолжение тысячелетнего роста в «режиме с обострением». Переход начинается не тогда, когда нарушается равновесие, а тогда, когда ответная реакция системы оказывается достаточной, чтобы началось движение к его восстановлению.

Интересно, что такая трактовка, отнюдь не совпадающая с описанной выше «двухфазной» схемой демографического перехода, тоже устраивает А. Коротаева и соавторов. Иначе нельзя понять их слова о том, что, «начиная с шестидесятых годов ХХ века, реальная динамика народонаселения Земли стала все больше отходить от гиперболической кривой, и к настоящему времени темпы роста населения резко понизились. Наблюдается то, что получило название глобального демографического перехода» [Коротаев и соавт. 2007 : 159-160]. А. Коротаев и соавторы (их состав несколько меняется) практически одновременно пишут о «спаде смертности в начале процесса демографического перехода (приведшем к демографическому взрыву)» [Коротаев и соавт. $2007^{\text {b: }}$ 43], и в то же время критикуют модель Кремера за то, что «она не описывает демографического перехода, то есть резкого снижения темпов роста населения Земли за последние четверть века» [Коротаев и соавт. 2007ª: 169].

Нет ясности и в датировке начала демографического перехода. Если С. Капица принимает общепринятую датировку («эпоха перехода для всех стран началась в середине XVIII в. и закончится к концу XXI в.» [Капица 1999а: 130]), то у Коротаева и соавторов речь идет о «последней четверти века», а А. Подлазов как-то писал даже, что «начало эпохи демографического перехода приходится на 1990 г., являющийся формальной датой крушения коммунистической системы» [Подлазов 2000].

Нельзя не видеть расхождений с «предметным знанием» и в сущностной трактовке последствий демографического перехода.

Теоретики демографического перехода давно уже осознали огромный социальный, экономический и биологический выигрыш, который несет этот переход. А. Подлазов утверждает, что «демографический переход... с биологической точки зрения является кризисом» [39].

Из теории демографического перехода следует, что снижение смертности лишает ее роли неуправляемого регулятора демографического процесса, одновременно делая жизнь 
человека намного более продолжительной и открывая новое пространство для «здоровьесберегающих» технологий, удлинения продолжительности здоровой жизни и оттеснения границ старости. Из концепции А. Подлазова вытекает лишь то, что «в силу невозможности опустить смертность ниже нуля человек не может развить жизнесберегающие технологии, которые востребовали бы большее количество представителей вида», и он рассматривает это как утрату «единственного ресурса, освоение которого и обеспечивало прогресс цивилизации» [50].

В логике теории демографического перехода, снижение рождаемости - это системная реакция на снижение смертности, когда к рождаемости переходит роль регулятора демографического процесса. Вместо этого сторонники гипотезы гиперболического роста повторяют распространенное объяснение, понятное «человеку с улицы», но весьма поверхностное, если действительно говорить о теории. Рождаемость, по их мнению, снижается «из-за роста уровня жизни основной массы населения Мир-Системы и вызванного этим ростом уровня образованности, обеспеченности медицинским обслуживанием (включая разнообразные методы и средства планирования семьи) социальным страхованием и т.п.» [Коротаев и соавторы 2010: 45]. Им даже не приходит в голову, что, возможно, они меняют местами причину и следствие.

В конце своей статьи А. Подлазов затрагивает важный вопрос о постпереходной стабилизации численности населения, которую он трактует как «кризис развития даже не цивилизационного, а видового масштаба»: вся история вида Homo sapience «была неразрывно связана с увеличением его численности», а теперь это увеличение прекратится [61]. С точки зрения теории демографического перехода, как я ее понимаю, постпереходная стабилизация, напротив, означает не кризис, а завершение кризиса, порожденного разбалансировкой рождаемости и смертности, и восстановление нарушенного демографического равновесия.

Выход из кризиса может оказаться болезненным и даже смертельно опасным для человеческой цивилизации, но не потому, что его результатом станет прекращение роста населения, а потому, что кризис затягивается и население мира продолжает расти, что действительно способно привести к «десоциализации и войнам», о которых пишет А. Подлазов. Но трудно согласиться с ним, когда, называя в качестве альтернативы такому варианту развития падение рождаемости ниже уровня воспроизводства, он рассматривает последнее просто как более мягкий вариант «элиминации «лишних» людей» [61]. Эти варианты различаются не «жесткостью» и «мягкостью», они диаметрально противоположны и отражают конкуренцию регуляторов. Мы не можем предвидеть, чем закончится эта конкуренция, и в этом смысле я разделяю обеспокоенность А. Подлазова. Но если что-то и повышает шансы на благоприятный исход, то это - скорейшее завершение кризиса и затухание глобального демографического взрыва, а оно требует падения рождаемости, на какое-то время даже и ниже уровня воспроизводства [Vishnevsky 2004: 274; Вишневский 2008: 85].

Суммируя сказанное, можно прийти к выводу, что за последние два-три десятилетия в работах ряда российских авторов, разделяющих гипотезу гиперболического роста населения, получила развитие система представлений о закономерностях 
демографического развития и о демографическом переходе как современном этапе этого развития, альтернативная общепринятой или, во всяком случае, наиболее распространенной в демографии. Родоначальником этого направления в России можно считать С.П. Капицу, хотя и он сам [Капица 1992: 66], и его последователи указывают на зарубежных предшественников, в частности, на уже упоминавшихся Фёрстера и соавторов.

Последователи Фёрстера и пропоненты гиперболического закона есть не только в России. Ход их мыслей, в том числе и когда речь идет о демографическом переходе, очень близок к ходу мыслей А. Подлазова, причем некоторые присутствующие в его работах идеи получают у них даже более четкое выражение. Так австралийский математик Рон Нильсен с большей определенностью подчеркивает парадигмальное отличие своих взглядов на экономическую и демографическую историю от общепринятых - это видно даже из названия его статьи («Смена парадигмы») [Nielsen 2014]. Он отрицает существование в человеческой истории этапов стагнации и роста и переходов между ними, равно как и ускорение экономического и демографического роста под влиянием созревших исторических перемен, а видит в истории лишь монотонные изменения, диктуемые гиперболическим законом. (Впрочем, переход от более быстрого к более медленному или от более медленного к более быстрому гиперболическому росту допускается). Он утверждает, что «промышленная революция и сопровождающий ее беспрецедентный технологический прогресс не оказали никакого влияния на экономический рост» [Nielsen 2014: 1950], а «быстрый рост населения, интерпретируемый как демографический взрыв... является естественным продолжением гиперболического роста» [Nielsen 2015: 3]. Согласно Р. Нильсену, теория демографического перехода неверна и ее давно нужно было отбросить [Там же: 2].

А. Подлазов не столь радикален в своих выводах, но у него тоже присутствует идея монотонного технологического и демографического роста. В целом же его статья, так же, как и его более ранние публикации, принадлежит к упомянутому исследовательскому направлению, которое требует большей или меньшей ревизии взглядов, сложившихся в демографической науке.

Подобный «ревизионизм» встречается в науке и может быть полезным, поскольку он приводит к конкуренции парадигм и, в конечном счете, к их смене. Но он оправдан лишь в том случае, если сторонники новой парадигмы убедительно показывают, «что они могут решить проблемы, которые привели старую парадигму к кризису» [Кун 1977: 201]. Насколько я могу судить, ни в статье А. Подлазова, ни в работах большинства его единомышленников основания для такой ревизии не представлены. (Правда, Р. Нильсен пытается найти такие основания в кажущемся ему несоответствии теории демографического перехода фактическим данным, но приведенные им несколько примеров едва ли покажутся убедительными сообществу демографов, изучающих эти данные на протяжении многих десятков лет). Отсутствие математической модели, о котором говорит А. Подлазов, само по себе едва ли может рассматриваться как признак кризиса парадигмы, а ее присутствие не есть доказательство опровержения общепринятых взглядов. 
Смысл обращения к математическому моделированию может быть двояким. Оно в равной степени способно служить как углублению и развитию сложившихся представлений, так и их коренному пересмотру, и то и другое может быть полезно. К сожалению, в случае со вспышкой интереса к гипотезе гиперболического роста населения, цель большинства сторонников этой гипотезы не заявлена и их отношение к «парадигмальным» идеям современной демографической науки не выражено.

Мне кажется, что приход математиков в демографию с первой целью - развития и углубления существующей демографической теории - был бы более продуктивным. Применительно к центральной теме, волнующей авторов работ о гиперболическом законе, здесь и в самом деле есть задачи, связанные с ограниченностью логистической модели, удовлетворяющей экологов, о чем писали, в частности, И. Пригожин и И. Стенгерс. Применительно к человеческому обществу, несомненно, есть основания «считать «несущую способность» систем не постоянной..., а функцией того, как используется система. Такое расширение модели позволит нам учесть некоторые дополнительные аспекты экономической деятельности, и в частности некоторые «эффекты усиления»... описать самоускоряющиеся свойства системы и пространственную дифференциацию различных уровней активности» [Пригожин, Стенгерс 1986: 258].

Хотелось бы признать, что такая расширенная модель, которая описывает и объясняет самоускоряющийся рост населения, как раз и представлена в статье А. Подлазова. Но настораживает замечание И. Пригожина и И. Стенгерс: «К моделированию сложных явлений следует относиться с осторожностью: в сложных системах дефиниция самих сущностей и взаимодействия между ними в процессе эволюции могут претерпевать изменения» [Пригожин, Стенгерс 1986: 267]. Кажется сомнительным, что весь сложнейший процесс роста числа людей на Земле на протяжении миллионов или хотя бы десятков тысяч лет можно смоделировать исходя из одного единственного параметра (коэффициента смертности), приписав ему имманентное свойство непрерывного снижения, каковыми он, на самом деле, не обладает. Может быть, я слишком буквально трактую слова о «расширении модели», но мне кажется, что они предполагают - при любых усложнениях - сохранение «философии» логистической модели, учитывающей взаимодействие населения и среды. Лежащая же в основе гипотезы гиперболического роста населения идея самодостаточности этого роста и его независимости от внешних условий делает эту гипотезу совершенно нереалистичной.

\section{ЛИТЕРАТУРА}

Аристотель. (1984). Политика // Аристотель. Собр. соч.: в 4 томах. Т. 4. М.: Мысль.

Вишневский А.Г. (1982). Воспроизводство населения и общество. М.: Финансы и статистика. 287 с.

(2008). Глобальные детерминанты низкой рождаемости // Синергетика. Будущее мира и России / Под ред. Г.Г. Малинецкого. Изд. ЛКИ: 71-91.

(2017). Нерешенные вопросы теории демографической революции //

Население и экономика. 2017, 1(1): 3-21. 
Гейзенберг В. (1967). Роль феноменологических теорий в системе теоретической физики // Успехи физических наук. 97 (4): 731-733.

Дэвис Л. (1996). Природные катастрофы. Том 1. Русич.

Капица С.П. (1992). Математическая модель роста народонаселения мира // Математическое моделирование. 4 (6): 65-79.

(1996). Феноменологическая теория роста населения Земли // Успехи физических наук. 166 (1): 63-79.

$\left(1999^{a}\right)$. Сколько людей жило, живет и будет жить на земле. Очерк теории роста человечества. М.: Международная программа образования. 240 с.

$\left(1999^{b}\right)$. Общая теория роста человечества: сколько людей жило, живет и будет жить на земле. М.: Наука. 190 с.

Кононов В. (2015). Мистика и истина гиперболического закона // Демографическое обозрение. 2 (2): 92-105.

Коротаев А.В.(2015). Глобальный демографический переход и фазы дивергенции конвергенции центра и периферии мир-системы // Вестник Института экономики Российской академии наук. 1:149-162.

Коротаев А.В., А.С. Малков, Д.А. Халтурина (2007ª). Законы истории: Математическое моделирование развития мир-системы. Демография, экономика, культура. Издание второе, исправленное и дополненное / Отв. редактор Н.Н. Крадин. М., КомКнига. $224 \mathrm{c}$.

Коротаев А.В., Н.Л. Комарова, Д.А. Халтурина (2007b). Законы истории: Вековые циклы и тысячелетние тренды. Демография, экономика, войны. Издание второе, исправленное и дополненное / Отв. редактор Н.Н. Крадин. М., КомКнига. 256 с.

Коротаев А.В., Халтурина Д.А., Малков А.С., Божевольнов Ю.В., Кобзева С.В., Зинькина Ю.В. (2010). Законы истории: Математическое моделирование и прогнозирование мирового и регионального развития / Отв. ред. Ф. Коротаев, В., Ю. Зинькина. Изд. 3-е, существенно перераб. и доп. М.: Изд. ЛКИ. 344 с.

Кун Т. (1977). Структура научных революций. М.: Прогресс. 299 с.

Ляпунов А.А. (1970). О рассмотрении биологии с позиций изучения живой природы как большой системы // Проблемы методологии системного исследования. М: Мысль: 184226.

Мальтус Т. Р. (1993). Опыт о законе народонаселения // Антология экономической классики в двух томах. Т.2. М.: Эконов: 5-134.

Монтескье Ш. (1955). Избранные произведения. М.: Государственное издательство политической литературы.

Новосельцев В.Н. (1978). Теория управления и биосистемы. Анализ сохранительных свойств. М.: Наука. 319 с.

Паевский В.В. (1935). Демографические работы Леонарда Эйлера // Леонард Эйлер 17071783. Сборник статей и материалов к 150 -летию со дня смерти. М-Л.: Издательство Академии наук СССР. М.-Л.: 103-110. 
Подлазов А.В. (2000). Теоретическая демография как основа математической истории. М.: ИПМ РАН им. M.В. Келдыша URL: http://keldysh.ru/papers/2000/prep73/prep2000_73.html (дата обращения: 01.02.2018).

(2001). Основное уравнение теоретической демографии и модель глобального демографического перехода. М.: Препринт ИПМ.

$5,1: 39-63$.

(2018). Глобальная демографическая теория // Демографическое обозрение,

Пригожин И., Стенгерс И. (1986). Порядок из хаоса. Новый диалог человека с природой. М.: Прогресс. 431 с.

Урланис Б.Ц. (2007). Рост населения в Европе. Опыт исчисления // Историческая демография. Избранные труды. М.: Наука: 19-308..

Цирель С.В. О феноменологической теории роста населения Земли С.П. Капицы. http://www.ccas.ru/manbios/tsirel_k.html

Birabin J.-N. (2006). The history of the human population from the first beginnings to the present day // Demography: Analysis and Synthesis. A Treatise in Population Studies / G. Caselli, J. Vallin, G. Wunsh, eds. Vol.3. Academic Press: 5-17.

Butzer K. R. (1976). Early hydraulic civilization. University of Chicago Press.

Caldwell J.C., Caldwell B.K. (2003). Was there a Neolithic mortality crisis? // Journal of Population Research. 20 (2): 153-168.

Chesnais J.-C. (1986). La transition démographique. Etapes, formes, implications économiques. Etude de séries temporelles (1720-1984) relatives à 67 pays. / INED. Travaux et documents. Cahier no 113. Presses Universitaires de France. 580 p.

Davis K. (1945). The world demographic transition // The Annals of the American Academy of Political and Social science. 237. World Population in Transition: 1-11.

Davis L. (1996). Prirodnye katastrofy [Natural Disasters]. V.1. Rusich.

Deevey E.S. (1960). The human population // Scientific American. 203 (3): 194-205.

Euler L. (1767). Recherches générales sur la multiplication du genre humain // Mémoires de l'Académie des sciences de Berlin 16 (1760): 144-164.

Foerster H. von, P. Mora, L. Amiot (1960). Domsday: Friday, 13 November, A.D. 2026 // Science 132: 1291-1295.

Gurven M., H. Kaplan (2007). Longevity among hunter-gatherers: A cross-cultural examination // Population and Development Review. 33 (2): 321-365.

HYDE (2011). History Database of the Global Environment 3.1. Netherlands Environmental Assessment Agency (PBL). URL:

http://themasites.pbl.nl/tridion/en/themasites/hyde/basicdrivingfactors/population/index2.html (дата обращения: 18.02.2018).

Goldewijk K., A. Beusen and P. Janssen (2010). Long-term dynamic modeling of global population and built-up area in a spatially explicit way: HYDE 3.1. // The Holocene 20(4) $565-573$.

Kremer M. (1993). Population growth and technological change: One million B.C. to 1990 // Q.J. Econ. 108(3): 683.

Landry A. (1982). La révolution démographique. Études et essais sur les problèmes de la population. INED. 
Livi Bacci M. (1992). A propos de la transition démographique // Transitions démographiques et sociétés. Chaire Quetelet / Sous la direction de D. Tabutin, T. Eggerickx, C. Gourbin. Louvain-la-Neuve: Academia - L'Harmattan. 1995: 449-457. (2012). A Concise History of World Population. Wiley-Blackwell.

McEvedy C., R. Jones (1979). Atlas of world population history. Penguin Books Ltd. and Allen Lane.

Nielsen R.W. (2014). Changing the Paradigm // Applied Mathematics. 5: 1950-1963.

(2015). Demographic transition theory contradicted repeatedly by data. URL: http://arxiv.org/ftp/arxiv/papers/1510/1510.00471.pdf (дата обращения: 01.02.2018).

Notestein F.W. (1945). Population - the long view // Food for the World / Theodore Schultz, ed. Chicago: University of Chicago Press: 37-57.

(1963). Closing statement // Proceedings of the Royal Society of London. Series B, Biological Sciences.159 (974). A Discussion on Demography: 245-252.

Rasmussen S., M.E. Allentoft, K. Nielsen, L. Orlando et al., (2015). Early divergent strains of Yersinia pestis in Eurasia 5,000 Years Ago // Cell 163, 571-582.

Süssmilch J. P. (1790-1792). Die göttliche Ordnung in den Veränderungen des menschlichen Geschlechts aus der Geburt, dem Tode und der Fortpflanzung desselben. Berlin, 5 Ausg., 1790-1792, T. I; T. II; T. III.

(1998) L'Ordre divine dans les changements de l'espèce humaine, démontré par la naissance, la mort et la propagation de celle-ci. Paris, INED, 1998.

Vishnevsky A.G. (2004). Replacement migration: is it a solution for the Russian Federation? // Policy Responses to Population Decline and Ageing. Population bulletin of the United Nations. Special Issue Nos. 44/45. UN, New York, 2004. (ST/ESA/SER.N44/45): 273-287. (2017). Unsolved problems in the theory of demographic revolution // Population and Economics. English version. 1. (1): 136-152.

WPP (2017). UN Population Division. World Population Prospects: The 2017 Revision, DVD Edition. 


\title{
THE DEMOGRAPHIC TRANSITION AND THE HYPOTHESIS OF HYPERBOLIC POPULATION GROWTH
}

\section{ANATOLY VISHNEVSKY}

\begin{abstract}
The article analyzes the interpretation of the demographic transition by the proponents of the hypothesis of the hyperbolic law of population growth. The author comes to the conclusion that over the last two or three decades a number of Russian authors who share this hypothesis have developed a system of ideas about the laws of demographic development and the demographic transition as a modern stage of this development, an alternative to the generally accepted "classical" theory. The task of the article is not so much to express disagreement with the proposed alternative, but rather to show the difference from the already existing ideas in its approaches and their consequences. At the same time, the author expresses a critical attitude to a number of postulates on which the hyperbolic law hypothesis is based, primarily to the underlying postulate of self-sufficiency of demographic growth and its independence from external conditions.
\end{abstract}

Key words: theoretical demography, demographic transition, demographic explosion, exponential growth, logistic growth, hyperbolic growth, demographic imperative, technological imperative, life-saving technologies, Neolithic demographic revolution, Neolithic mortality crisis.

\footnotetext{
ANATOly Vishnevsky (avishnevsky@hse.ru), NATIONAL RESEARCH UNIVERSITY Higher SchOOL OF ECONOMICS, RUSSIA.

DATE RECEIVED: DECEMBER 2017.
}

\section{REFERENCES}

Aristotle. (1984). Politika (Politics) // Collected works in 4 volumes. V.4. Moscow: Mysl'.

Birabin J.-N. (2006). The history of the human population from the first beginnings to the present day // Demography: Analysis and Synthesis. A Treatise in Population Studies / G. Caselli, J. Vallin, G. Wunsh, eds. Vol.3. Academic Press: 5-17.

Butzer K. R. (1976). Early hydraulic civilization. University of Chicago Press.

Caldwell J.C., Caldwell B.K. (2003). Was there a Neolithic mortality crisis? // Journal of Population Research. 20 (2): 153-168.

Chesnais J.-C. (1986). La transition démographique. Etapes, formes, implications économiques. Etude de séries temporelles (1720-1984) relatives à 67 pays. / INED. Travaux et documents. Cahier no 113. Presses Universitaires de France. 580 p.

Davis K. (1945). The world demographic transition // The Annals of the American Academy of Political and Social science. 237. World Population in Transition: 1-11.

Davis L. (1996). Prirodnye katastrofy [Natural Disasters]. V.1. Rusich.

Deevey E.S. (1960). The human population // Scientific American. 203 (3): 194-205.

Euler L. (1767). Recherches générales sur la multiplication du genre humain // Mémoires de l'Académie des sciences de Berlin 16 (1760): 144-164.

Foerster H. von, P. Mora, L. Amiot (1960). Domsday: Friday, 13 November, A.D. 2026 // Science 132: 1291-1295. 
Goldewijk K., A. Beusen and P. Janssen (2010). Long-term dynamic modeling of global population and built-up area in a spatially explicit way: HYDE 3.1. // The Holocene 20(4) $565-573$.

Gurven M., H. Kaplan (2007). Longevity among hunter-gatherers: A cross-cultural examination // Population and Development Review. 33 (2): 321-365.

Heisenberg W. (1967). Rol' fenomenologicheskikh teoriy v sisteme teoreticheskoy fiziki (The role of phenomenological theories in the system of theoretical physics [Die Rolle der phänomenologischen Theorien im System der theoretischen Physik]) // Uspekhi fizicheskikh nauk. 97, 4: 731-733.

HYDE (2011). History Database of the Global Environment 3.1. Netherlands Environmental Assessment Agency (PBL). URL: http://themasites.pbl.nl/tridion/en/themasites/hyde/basicdrivingfactors/population/index2.html (accessed: 18.02.2018).

Kapitza S.P. (1992). Matematicheskaya model' rosta narodonaseleniya mira [Mathematical model of World population growth] // Matematicheskoe modelirovanie. 4, 6: 65-79.

(1996). Fenomenologicheskaya teoriya rosta naseleniya Zemli [Phenomenological theory of World population growth] // Uspekhi fizicheskikh nauk. 166, 4: 63-80.

$\left(1999^{a}\right)$. Skol'ko lyudey zhilo, zhivet i budet zhit' na Zemle. Ocherk teorii rosta chelovechestva [How many people lived, live and will live on Earth: An essay on humankind growth]. Moscow: Mezhdunarodnaya programma obrazovaniya. $240 \mathrm{p}$.

$\left(1999^{b}\right)$. Obshchaya teoriya rosta chelovechestva: skol'ko lyudey zhilo, zhivet i budet zhit' na zemle [General Theory of humankind Growth: How many people lived, live and will live on Earth]. Moscow: Nauka. 190 p.

Kononov V.G. (2015). Mistika i istina giperbolicheskogo zakona [Mysticism and truth of hyperbolic law] // Demograficheskoe obozrenie [Demographiv Review]. 2(2): 92-105.

Korotaev A.V. (2015). Global'nyy demograficheskiy perekhod i fazy divergentsii-konvergentsii tsentra i periferii Mir-sistemy [Global demographic transition and phases of divergenceconvergence of the center and the periphery of the World system] // Vestnik instituta ekonomiki Rossiyskoy Akademii nauk [Bulletin of the Russian Academy of Science]. 1: 149-162.

Korotaev A.V., A.S. Malkov, D.A. Khalturina (2007ª). Zakony istorii: Matematicheskoe modelirovanie razvitiya Mir-Sistemy. Demografiya, ekonomika, kul'tura. Izd. 2 e, ispr. i dop. [Laws of history: Mathematical modeling of development of world-system. Demography, economy, culture. 2nd edition, revised and extended] / N.N. Kradin, ed. Moscow: KomKniga. 224 p.

Korotaev A.V., N.L. Komarova, D.A. Khalturina $\left(2007^{\mathrm{b}}\right)$. Zakony istorii: Vekovye tsikly i tysyacheletnie trendy. Demografiya, ekonomika, voyny. Izd. 2 e, ispr. i dop. [Laws of history: Secular cycles and thousand-year trends. Demography, economy, wars. 2nd edition, revised and extended] / N.N. Kradin, ed. Moscow: KomKniga. 255 p.

Korotaev A.V., D.A. Khalturina, A.S. Malkov, Bozhevol'ov Yu.V., Kobzema S.V., Zin'kina Yu.V. (2010). Zakony istorii: Matematicheskoe modelirovanie i prognozirovanie mirovogo i regional'nogo razvitiya. Izd. 3-e, ispr. i dop. [Laws of history: Mathematical modeling and forecasting of world and regional development. 3rd edition, substantially revised and extended]. Moscow: Publishing house LKI. 344 p. 
Kremer M. (1993). Population growth and technological change: One million B.C. to 1990 // Q.J. Econ. 108(3): 683.

Kuhn T.S. (1977). Struktura nauchnykh revolyutsiy [The structure of scientific revolutions]. Moscow: Progress. 299 p.

Landry A. (1982). La révolution démographique. Études et essais sur les problèmes de la population. INED.

Livi Bacci M. (1992). A propos de la transition démographique // Transitions démographiques et sociétés. Chaire Quetelet / Sous la direction de D. Tabutin, T. Eggerickx, C. Gourbin. Louvain-la-Neuve: Academia - L'Harmattan. 1995: 449-457.

(2012) A concise history of World population. Wiley-Blackwell.

Lyapunov A.A. (1970). O rassmotrenii biologii s pozitsiy izucheniya zhivoy prirody kak bol'shoy sistemy [On the consideration of biology from the standpoint of studying living nature as a large system] // Problemy metodologii sistemnogo issledovaniya [Problems of methodology of system analysis]. Moscow: Mysl’: 184-226.

Malthus T.R. (1993). Opyt o zakone narodonaselenia [An Essay on the Principle of Population] // Antologiya ekonomicheskoy klassikiy. V dvukh tomakh [Anthology of economic classics in two volumes]. Moscow: Econov. 2: 5-134.

McEvedy C., R. Jones (1979). Atlas of world population history. Penguin Books Ltd. and Allen Lane.

Montesquieu Ch. (1955). Izbrannye proizvedeniya [Selected Works]. Moscow. Gosudarstvennoe izdatel'stvo poli'icheskoy literatury.

Nielsen R.W. (2014). Changing the Paradigm // Applied Mathematics. 5: 1950-1963.

(2015). Demographic transition theory contradicted repeatedly by data. URL: http://arxiv.org/ftp/arxiv/papers/1510/1510.00471.pdf (accesses: 01.02.2018).

Notestein F.W. (1945). Population - the long view // Food for the World / Theodore Schultz, ed. Chicago: University of Chicago Press: 37-57.

(1963). Closing statement // Proceedings of the Royal Society of London. Series B, Biological Sciences.159 (974). A Discussion on Demography: 245-252.

Novosel'tsev V.N. (1978). Teoriya upravlenia i biosistemy. Analiz sokhranitel'nykh svoystv

[Control theory and biosystems. Analysis of maintaining properties]. Moscow: Nauka. 319 p.

Paevskiy V.V. (1935). Demograficheskie raboty Leonarda Eylera [Demographic works of Leonhard Euler] // Leonard Eyler 1707-1783. Sbornik statey i materialov k 150-letiyu so dnya smerti [Leonhard Euler 1707-1783. Collection of articles and materials for the 150th anniversary of the death]. Moscow-Leningrad: Izdatel'stvo Akademii nauk SSSR: 103-110.

Podlazov A. (2000). Teoreticheskaya demografiya kak osnova matematicheskoy istorii [Theoretical demography as the basis of mathematical history]. Moscow: Institut Prikladnoy Matematiki. URL: http://keldysh.ru/papers/2000/prep73/prep2000_73.html (accessed: 01.02.2018).

(2001). Osnovnoe uravnenie teoreticheskoy demografii i model' global'nogo demograficheskogo perekhoda [Bfsic equation of the theoretical demography and a model of the global demographic transition]. Working paper. Institut Prikladnoy Matematiki. 
(2018). Global'naya demograficheskaya teoriya [Global demographic theory] // Demograficheskoe obozrenie [Demographic Review]. 5 (1): 39-63.

Prigogine I., I. Stengers (1986). Poryadok iz khaosa. Novyy dialog cheloveka s prirodoy [Order out of chaos. Man's new dialogue with nature]. Moscow: Progress. $431 \mathrm{p}$.

Rasmussen S., M.E. Allentoft, K. Nielsen, L. Orlando et al., (2015). Early divergent strains of Yersinia pestis in Eurasia 5,000 Years Ago // Cell 163, 571-582.

Süssmilch J.P. (1790-1792). Die göttliche Ordnung in den Veränderungen des menschlichen Geschlechts aus der Geburt, dem Tode und der Fortpflanzung desselben. Berlin, 5 Ausg., 1790-1792, T. I; T. II; T. III.

(1998) L'Ordre divine dans les changements de l'espèce humaine, démontré par la naissance, la mort et la propagation de celle-ci. Paris, INED, 1998.

Tsirel' S.V. O fenomenologicheskoy teorii rosta naseleniya Zemli S.P.Kapitzy [On the Kapitza's phenomenological theory of the World population growth] URL: http://www.ccas.ru/manbios/tsirel_k.html (accessed: 01.02.2018).

Urlanis B.Ts. (2007). Rost naseleniya v Evrope. [Population growth in Europe] // Istoricheskaya demografiya. Izbrannye trudy [Historical demography. Selected Works]. Moscow: Nauka: 19-308.

Vishnevsky A.G. (1982). Vosproizvodstvo naseleniya i obshchestvo [Human population reproduction and society]. Moscow: Finansy i statistika. 287 p.

(2004). Replacement migration: is it a solution for the Russian Federation? // Policy Responses to Population Decline and Ageing. Population bulletin of the United Nations. Special Issue Nos. 44/45. UN, New York, 2004. (ST/ESA/SER.N44/45): 273-287.

(2008). Global'nye determinanty nizkoy rozhdaemosti [The global determinants of low fertility] // Sinergetika. Budushchee mira i Rossii [Synergetics. The future of the World and Russia]. G.Malinetskiy, ed. Publishing house LKI: 71-91

(2017). Unsolved problems in the theory of demographic revolution // Population and Economics. English version. 1. (1): 136-152.

WPP (2017). UN Population Division. World Population Prospects: The 2017 Revision, DVD Edition. 